İş ve İnsan Dergisi I The Journal of Human and Work

Y1l | Year: Ekim | October 2018

Cilt-Sayı | Volume-Issue: 5 (2)

ss I pp: $125-143$

doi: 10.18394/iid.375457

e-ISSN 2148-967X

http://dergipark.gov.tr/iid/

Araştırma Makalesi

\title{
Aşırı İş Yükünün İş ve Yaşam Doyumu Üzerindeki Etkisi: \\ İşe Bağlı Gerginliğin Aracı Rolü
}

Effects of Work Overload on Job and Life Satisfaction:

Mediating Role of Work-Related Strain

\author{
Engin Kanbur ${ }^{\mathrm{a}}$
}

\section{MAKALE BİLGİSI}

\section{Anahtar Kelimeler:}

Aşırı İş Yükü, Iș Doyumu

Yaşam Doyumu, İşe Băgll

Gerginlik.

Tarihler:

Geliş 05 Ocak 2018

Düzeltme geliş 22 Nisan

2018

Kabul 01 Mayis 2018

\section{ÖZ}

Bu çalışmada, çalışanların aşırı iş yükü düzeylerinin iş ve yaşam doyumları üzerindeki etkisinde işe bağll gerginliğin aracılı (tam/kısmi) rolü incelenmiştir. Araştırmanın örneklemi, Malatya ilinde faaliyetlerini sürdüren bir tekstil işletmesinde görev yapan 528 çalışandan oluşmaktadır. Araştırma verileri anket tekniği kullanılarak toplanmıştır. Araştırma değişkenlerinin ölçülmesinde Aşırı Işs Yükü Ölçeği, Iș Doyumu Ölçeği, Yaşam Doyumu Ölçeği ve Ișe Bağlı Gerginlik Ölçeği kullanılmıştır. Ölçeklerin güvenilirlikleri Cronbach Alfa, geçerlilikleri ise doğrulayıc faktör analizi ile test edilmiştir. Ayrıca değişkenler arasındaki ilişsiyi belirlemek için korelasyon analizi, aracılık rolünü tespit etmek için ise hiyerarşik regresyon analizinden yararlanılmıștır. Araștırmanın bulgularına göre; çalışanların așırı iş yükü düzeylerinin iș ve yaşam doyumu ile negatif ve anlamll, işe bağlı gerginlik ile pozitif ve anlamlı olarak ilişkili olduğu görülmektedir. İşe bağll gerginliğin iş ve yaşam doyumu üzerinde negatif etkisinin olduğu tespit edilmiştir. Sonuç olarak çalışanların aşırı iş yükü düzeylerinin hem iş doyumu hem de yaşam doyumu üzerindeki etkisinde işe bağll gerginliğin kismi aracılık rolünün olduğu vurgulanabilir.

\begin{abstract}
A B S T R A C T
In this study, the mediating role (full / partial) of work-related strain on the effects of work overload levels of employees on their job and life satisfaction was examined. The sample of the research consists of 528 employees who are working in a textile business that continues its activities in the province of Malatya. Data of the research was collected by means of questionnaire technique. Work Overload Scale, Job Satisfaction Scale, Life Satisfaction Scale and Work-Related Strain Scale were utilized for measuring the variables of the research. The reliability of the scales was analyzed by Cronbach Alpha and their validity was analyzed by confirmatory factor analysis. Additionally, correlation analysis was used for measuring the relationships between variables and hierarchical regression analysis was used for determining the mediating role. According to the findings; it can be seen that the work overload levels of employees are negatively and significantly correlated with job and life satisfaction while positively and significantly correlated with work-related strain. It was found that work-related strain has a negative and significant effect on job and life satisfaction. Ultimately, it can be emphasized that work-related strain has a partial mediating role on the effects of work overload levels of employees both on their job and life satisfaction.
\end{abstract}

\footnotetext{
a Iletişim kurulacak yazar, Dr. Öğr. Üy., Kastamonu Üniversitesi, Sicil Havacılık Yüksekokulu, Kastamonu, Türkiye. E-mail: ekanbur@kastamonu.edu.tr.ORCID:0000-0002-6261-9314
} 


\section{GİRIŞ}

Örgütler, küresel iş yaşamında rakipleri ile rekabet edebilmek ve bunu sürdürülebilir kılmak, tüketicilerin istek ve taleplerini zamanında ve kaliteli olarak karşılayabilmek, maliyetleri azaltmak ve kar oranını yükseltmek diğer bir deyişle hayatta kalabilmek için büyük bir mücadele vermektedirler (Çelik \& Çıra, 2013). Bu mücadelenin başarıya ulaşabilmesi için çalışanlarının performansına, yetenek ve kabiliyetlerine, bilgilerine, yaratıcılıklarına ve girişimciliklerine ihtiyaç duymaktadırlar. Örgütlerin, çalışanlarına ihtiyaç duydukları özellikleri kazandırması kolay bir iş değildir. Çalışanların, mutlu olmadıkları, stres ve belirsizlik yaşadıkları örgütlerde bu tür özelliklerini ortaya koyması, işten doyum sağlaması ve bu doyumun yaşamlarına yansıması oldukça güçtür.

İş doyumu, en genel anlamıla bireyin iş yaşamından duyduğu haz ve mutluluk olarak tanımlanırken (Keser, 2006) aynı zamanda bireyin toplam iş çevresinden yani işin kendisinden, yöneticilerden ve iş arkadaşlarından elde etmeye çaba harcadığ 1 rahatlatıcı ve iç yatıştırıcı bir duygudur (Eroğlu, 2011). İş doyumu, bireylerin yaptıkları işten sağladıkları memnuniyet veya hoşnutluk düzeyine göre değişmektedir. İşinden memnun olan bireyler için iş doyumu yüksek olabilirken, işinden memnun olmayan bireylerin ise iş doyumunun düşük olması beklenmektedir (Ertürk \& Keçelioğlu, 2012). Yaşam doyumu ise bireyin belirlemiş olduğu standart ve ilkelere uygun olarak yaşamının tamamını olumlu değerlendirmesi ve memnun kalması (Diener, Emmons, Larsen \& Griffin, 1985), dolayısıyla bireyin yaşamdan beklediği, istediği ve kendine layık gördüğü kriterler ile içinde bulunduğu ve hâlihazırdaki yaşam şartları arasındaki kıyaslamaları sonucu yaşamı hakkında bir değerlendirme yapması olarak açıklanmaktadır (Çeçen, 2007; Çevik \& Korkmaz, 2014).

İş ve yaşam doyumunun sağlanmasında rol oynayan çok sayıda değişken farklı çalışmalarda incelenmiş olmasına rağmen çalışanların örgüt içerisinde sergilediği birçok davranışın nedenini oluşturan iş ve yaşam doyumu üzerinde etkili olabilecek öncüllerin incelenmesi pek çok araştırmacının ele aldığı bir çalışma alanı olarak yazındaki önemini korumaktadır. Bu çalışmanın iki temel değişkeni olarak aşırı iş yükü ve işe bağlı gerginlik, çalışanların iş ve yaşam doyumu üzerinde etkisi olduğu düşünülen kavramlar olarak karşımıza çıkmaktadır. Çalışanların sahip olduğu özellikleri örgütsel amaçlar doğrultusunda kullanabilmesi için işten kaynaklanan bazı olumsuz durumların örgütler tarafindan düzeltilmesi veya önlem alınması gerekmektedir ki aşırı iş yükü ve işe bağlı gerginlik bu olumsuz durumlar arasında yer almaktadır (Berg \& Hallberg, 1999; Dorrian, Baulk \& Dawson, 2011).

İş yükü, bireyin belirlenmiş çalışma zamanı dâhilinde bir kazanım elde etmek için yerine getirdiği görevlerdir. Bireyin yaptığı görevlerin miktarı, zorluk derecesi, karmaşıklığı arttıkça bu doğrultuda iş yükünün de artması beklenen sonuçlardan biridir (Çakıcı, Özkan \& Akyüz, 2013). Aşırı iş yükü, çalışanların örgüt içinde yüklendiği rollerin fazla olması, kapasitesini zorlayıcı, fiziksel ve zihinsel olarak yıpratıcı işlerin yerine getirilmesi olarak belirtilmektedir (Greenhaus, Parasuraman, Granrose, Rabinowitz \& Beutell, 1989). İşe bağl1 gerginlik, bireylerin iş ile ilgili değişiklikleri tehdit ya da tehlike olarak algıladığı, örgüt tarafindan uygun ortam sağlandığında uyum gösterdiği, sağlanmadığında ise kendisini tehdit altında hissettiği olayların bütünüdür (Özyer, 2016). İşe bağlı gerginlik; iş hayatında kaçınılmaz, olmazsa olmaz bir tecrübe olmakla beraber, bu gerginliklerin sıklığ 1 , yoğunluğu ve süresi bireyin bu durumla baş edebilme gücünden fazla olduğunda birtakım sıkıntılar veya sorunlar ortaya çıkmaktadır (Tokuç, Turunç \& Ekuklu, 2015). İş kaynaklı gerginliğin oluşumuna zemin hazırlayan etmenler arasında aşırı iş yükü ayrı bir önem taşımaktadır. Çünkü iş yükünün aşırı olma niteliği, bireyin rutin zaman içerisinde yaptı̆g 1 işlerden daha fazla iş yapması halinde ortaya çlkan bir durumdur ve bireyin üzerinde olumsuz bir baskı oluşturmaktadır (Reid \& Nygren, 1988). İş merkezli bu baskının bireyin yüklendiği işe bağlı gerginlik olarak kendini hissettirmesi beklenmektedir.

İş ve yaşam doyumunun öncülü olarak nitelendirilebilen aşırı iş yükü ve işe bağlı gerginlik kavramlarına ilişkin tanımlardan hareketle aşırı iş yükü deneyimlerinin çalışanların işten sağladığı doyum ve bunun yansıması olan yaşam doyumu üzerindeki negatif etkilerinde deneyimlenen işe bağlı gerginliğin üstlendiği rolün incelenmesine ihtiyaç duyulmaktadır. Bu bağlamda çalışanların aşırı iş yükü algılamalarının iş doyumları üzerindeki etkisi ve bu etkide işe bağlı gerginliğin aracı rolünün olup olmadığı çalışmanın sorunsallarından biridir. Bunun yanı sıra, çalışanların aşırı iş yükü algılamalarının yaşam doyumları üzerindeki etkisi ve bu etkide işe bağl1 gerginliğin aracı rolünün olup olmadığı çalışmanın diğer sorunsalı olarak belirlenmiş̧tir.

Çalışmada ele alınan aracılık rolünde yer alan değişkenlerle ilgili yazının detaylı taraması yapılmıştır. Yazın taraması sonucunda aşırı iş yükünün iş ve yaşam doyumu üzerindeki etkisinde 
işe bağlı gerginliğin aracı rolünü inceleyen çalışmaya rastlanamamıştır. Dolayısıyla yazında daha önce araştırılmamış bir konuyu araştırmak ve sonuçlarını paylaşmak, gerek araştırmanın önemi ve yazına katkısı gerekse de böyle bir araştırmaya olan ihtiyacın giderilmesi bakımından son derece önemlidir. $\mathrm{Bu}$ çalışma ülkemiz ihracatına ve istihdamına sağladığı katkılarla öne çıkan tekstil sektöründe yer alan bir işletmenin çalışanları ile yürütülmesi açısından da önem arz etmektedir. Artan rekabet koşullarında dinamikliği ve üretkenliği ile binlerce kişiye istihdam sağlayan tekstil sektörü emek yoğun yapısı nedeniyle kaçınılmaz olarak çalışanların aşırı iş yükünü ve işe bağlı gerginliği en çok deneyimlediği iş kolları arasında yer almaktadır. $\mathrm{Bu}$ sektörün temel sorunları olarak dikkat çeken sektörel daralma, kayıtdışı istihdam, artan taşeron üretim, uzun mesailer ve haftasonu çalışmaları beraberinde daha fazla iş yükünü ve işe bağlı gerginliği getirirken çalışanların iş ve yaşam doyumunda da azalmaya neden olacaktır. Dolayısıyla tekstil sektöründe çalışanlar ve(veya) kendisine bu sektörde yer bulmayı arzulayanlar için iş ve yaşam doyumunda aşırı iş yükünün etkisini ortaya koyması nedeniyle de çalışmanın sonuçlarının önemli olduğuna inanılmaktadır. Elde edilen bulguların özellikle bu sektörün istihdam politikalarının değerlendirilmesinde ve çalışanların iş ve yaşam doyumuna ulaşmalarında gerekli koşulların belirlenmesinde dikkate alınacak kriterler açısından katk1 sağlayacağı da düşünülmektedir. $\mathrm{Bu}$ kapsamda çalışmanın hem araştırmacılar hem uygulayıcılar için fayda sağlayıcı nitelikte olduğuna inanılmaktadır.

\section{KAVRAMSAL CCERÇEVE}

\subsection{Așırı İş Yükü}

İş hayatının temel yapı taşlarından biri olan iş yükü, bireyin örgütsel rolü ile ilgili olarak belirli bir süre içerisinde belirli bir standartta yerine getirmesi gereken iş miktarı olarak tanımlanmaktadır (Maslach \& Leiter, 1997). Bireyin örgüt içinde yapmakla görevlendirildiği işlerin tamamı olan iş yükü, çalışma zamanına göre bireye düşen iş miktarı şeklinde de tanımlanmaktadır (Qureshi vd., 2013; Baltacı, 2017). İş yükü, örgütsel açıdan bakıldığında verimlilik ve performans, bireysel açıdan bakıldığında ise işin (görevi) gereklerini yapmak için geçirilen süre ve harcanan enerjiyi (emek) ifade etmektedir (Ardıç \& Polatcı, 2009).

Aşırı iş yükü en genel anlamıyla, bireyin örgüt tarafindan kendisine verilen rolün gereği olarak işin normalinden fazla olduğuna dair algısıdır (Keser, 2006). Aşırı iş yükü, çalışanların örgüt içinde yüklendiği rollerin fazla olması, kapasitesini zorlayıc1, fiziksel ve zihinsel olarak yıpratıcı işlerin yerine getirilmesi olarak belirtilmektedir (Greenhaus vd., 1989). Așırı iş yükü, belirli bir zaman baskısı altında işi bitirme zorunluluğu, bireyin işin niteliklerine göre yetersiz kalması veya işin standardının yüksek olması olarak da belirtilmektedir (Sabuncuoğlu \& Tüz, 2003). Așırı iş yükü çalışan için önemli olduğu kadar, örgüt için de önemli bir konudur. Çalışanlar aşırı iş yükü nedeniyle tükenmişlik, iş tatminsizliği, işe karş1 stres ve gerginlik yaşarken, örgüt ise çalışanların düşen performansından dolayı verimsizlik yaşayabilmektedir (Gümüştekin \& Öztemiz, 2005). Aşırı iş yükü niteliksel ve niceliksel olarak iki farklı şekilde değerlendirilmektedir. Niteliksel açıdan bakıldığında iş yükü, bireyin sahip olduğu yetenekler ile işin gerekleri arasındaki ilişkiyi açıklar. İşin gerekleri bireyin yeteneklerinden fazla olduğu durumda iş yükü de ağır olacaktır. Niceliksel açıdan bakıldığında iş yükü, yapılacak iş ile bu işin bitirilmesi için uygun görülen zaman arasındaki ilişkiyi açıklar. Bu süre az ise iş yükü ağır, fazla ise iş yükü hafif olacaktır (Cam, 2004; Çelik, 2016).

Yazında, çalışanların iş yükü düzeyleri ile farklı değişkenler arasındaki ilişkiyi ele alan bazı araştırmalar yürütülmüştür. Van ve Geurts (2001) çalışmalarında, aşırı iş yükü altında görevlerini yapan çalışanların tükenmişlik sendromu yaşadığını ve ruh sağlıklarını kaybetme riski taşıdıklarını belirtmektedirler. Greenglass, Burke ve Riksenbaum (2001) çalışmalarında, aşırı iş yükünün çalışanların duygusal olarak tükenmelerine neden olduğunu ortaya koymaktadırlar. Geurts, Kompier, Roxburgh ve Houtman (2003) araştırmalarında, aşırı iş yükünün çalışanların iyi olma halini olumsuz olarak etkilediği ve çalışanları huzursuzluğa sevk ettiğini ifade etmektedirler. Brown, Jones ve Leigh (2005) çalışmalarında, aşırı iş yükünün iş performansı, öz-yeterlilik ve dayanıklılık gibi pozitif örgütsel davranışları engellediğini belirtmektedirler. Hancock ve Verwey (1997) ile Dorrian ve arakadaşları (2011) çalışmalarında, aşırı iş yükünün çalışanları fiziki olarak güçsüz düşürdüğünü ve yorgunluğa neden olduğunu belirtmektedirler. Tayfur ve Aslan (2012) çalışmalarında, aşırı iş yükü ile iş-aile çatışması, duygusal tükenme ve işe karşı duyarsızlaşma arasında pozitif bir ilişkinin olduğunu ifade etmektedirler. Çelik ve Çıra (2013) çalışmalarında; aşırı iş yükü ile örgütsel vatandaşlık davranışı ve iş performansı arasında negatif, aşırı iş yükü ile işten ayrılma niyeti arasında ise pozitif bir ilişkinin olduğunu belirtmektedirler. 


\section{2. İş Doyumu}

İş doyumu en genel anlamıyla bireyin iş yaşamından duyduğu, hissettiği veya algıladığı haz, huzur ve mutluluk olarak tanımlanmaktadır (Keser, 2006). İş doyumu, bireyin toplam iş çevresinden yani işin kendisinden, yöneticilerden ve iş arkadaşlarından elde etmeye çaba harcadığı rahatlatıcı ve iç yatıştıııcı bir duygudur (Eroğlu, 2011). İş tatmini denildiğinde, işten kazanılan maddi çıkarlar ile bireyin birlikte aynı ortamda çalışmaktan zevk aldığı işyeri arkadaşları ve ortaya ürün çıkartmanın verdiği mutluluk akla gelmektedir (Eren, 2004). Ayrıca iş doyumu, bireyin yaptığı işe olan saygisı sonucunda ortaya çıkan olumlu tutumları kapsamaktadır. Ancak dinamik bir yapıya sahip olan iş doyumu, örgütte bir defa sağlandığında hep aynı olacağı anlamına gelmemektedir (Sparks, Corcoran, Nabors \& Hovanitz, 2005; Şeker \& Zırhlıoğlu, 2009).

İş doyumu, bireyin, örgüt içinde daha katılımcı olabilmesi, yüksek performans gösterebilmesi, rol gereklerini en iyi düzeyde gerçekleştirebilmesi, daha üretken çalışabilmesi, düzeni bozan, verimliliği düşüren davranışlardan uzak durması, yaratıcı, yenilikçi, proaktif ve girişimci davranış sergileyebilmesi için gerekli olan motive edici araçların başında gelmektedir (Sünter, Canbaz, Dabak, Öz \& Pekşen, 2006). Bu kapsamda iş doyumu ile motivasyon kuramları arasında sıkı bir ilișki bulunmaktadır. Blau'nun "Sosyal Mübadele Kuramı", Locke'un "Bekleyiş Kuramı", Maslow'un "İhtiyaçlar Hiyerarşisi”, Eisenberger'ın "Örgütsel Destek Kuramı", Vroom'un "Beklenti Kuramı", Herzberg'in "Çift Hijyen Kuramı", Adams'ın "Eşitlik Kuramı" ve Salancik ve Pfeffer'ın "Kişilerarası Karşılaştırma Kuramı" gibi kuramların temelinde bireyin motive olması ve bunun neticesinde işinden haz, memnuniyet ya da doyum sağlaması bulunmaktadır (Eğinli, 2009; Kanbur, Kanbur \& Özdemir, 2017).

Yazında iş doyumu ile farklı değişkenler arasındaki ilişkiyi ele alan bazı araştırmalar yürütülmüştür. İş doyumunun; örgütsel vatandaşlık davranışı (Gürbüz, Erkuş \& Sığrı, 2010; Gürbüz \& Yüksel, 2008; Schappe, 1998; Şahin, 2011), örgütsel bağl1lik (Feather \& Rauter, 2004; Lok \& Crawford, 2004; Lum, Kervin, Clark, Reid \& Sirola, 1998), iş performans1 (Pritchard \& Karasick, 1973; Sy, Tram \& O'Hara, 2006), çalışan tutumları (Saari \& Judge, 2004), örgütsel adalet (Yıldırım, 2007), yaşam doyumu (Judge, Bono, Erez \& Locke, 2005; Judge \& Watanabe, 1993; Tait, Padgett \& Baldwin, 1989) ile pozitif ve anlamlı bir ilişkisinin olduğu görülmektedir. Bunun yanında iş doyumunun; işten ayrilma niyeti (Egan, Yang \& Bartlett, 2004; Hellman, 1997), stres (Naima, 1998), rol belirsizliği ve rol çatışması (Currivan, 1999), tükenmişlik (Oral \& Köse, 2011; Tett \& Meyer, 1993), iş-aile ve aileiş çatışması (Bruck, Allen \& Spector, 2002) ile negatif ve anlamlı bir ilişkisinin olduğu belirtilmektedir.

\subsection{Yaşam Doyumu}

Yaşam doyumu kavramı ilk olarak Neugarten, Havgghurst ve Tobgn (1961) tarafindan kullanılmakta ve "bireylerin yaşamdan beklentileri ile sahip oldukları arasında karşılaştırma yapması neticesinde ortaya çıkan durum" olarak tanımlanmaktadır (Akın \& Yalnız, 2015). Diener ve arakadaşları (1985) için yaşam doyumu, bireyin belirlemiş olduğu standartlara uygun olarak yaşamının tamamını olumlu değerlendirmesi ve memnun kalmasidir (Veenhoven, 1991; Chang, Yang \& Yu, 2017). Bireyin hem iş hayatında hem de sosyal hayatında karşı karşıya kaldığı olumlu ya da olumsuz durumlar onun hayattan aldığı hazzı ya da doyumu etkilemektedir. Bu bağlamda yaşam doyumu iş ve sosyal hayatın bir sentezidir (Avşaroğlu, Deniz \& Kahraman, 2005; Luhmann, Lucas, Eid \& Diener, 2013: 39). Diener ve Lucas'a (1999) göre yaşam doyumu, bireyin dünü, bugünü ve yarını ile ilişkilidir. Yani bireyin geçmişte yaşadığı, mevcut durumda yaşadığı ve gelecekte yaşayacağı hayattan alacağı toplam haz veya doyumdur.

Yaşam doyumu öznel iyi olma kavramı ile yakın ilişkilidir. Öznel iyi olma, bireyin hayatının tamamında karşı karşıya kaldığı ve tecrübe ettiği durumlara karşı gösterdiği duygusal tepkileri ve bilişsel değerlendirmeleri içermektedir (Diener, 2000; Dost, 2007; Ferreira vd., 2013; Kanbur, 2015; Welsch, 2009). Bilişsel kurama göre yaşam doyumu, kişinin mevcut yaşam şartlarının daha önce belirlediği veya kurguladığı yaşam şartlarına uygun olup olmadığını karşılaştırması sonucu oluşan bilişsel yargı olarak ifade edilmektedir. Duyuşsal kurama göre yaşam doyumu, bireyin yaşamı ile ilgili olumlu olan duygularının olumsuz duyguları karşısında üstün gelmesine ilişkin kasıtlı deneyimi olarak tanımlanmaktadır (Akgündüz, 2013). O halde yaşam doyumu, bireyin aile, arkadaş, iş ve sosyal çevre gibi tüm yaşamını kuşatan ve yaşamına etkisi olan olay, kişi ve durumlara karşı gösterdiği duygusal tepkiler ve bilişsel değerlendirmeler şeklinde ifade edilmektedir (Çivitçi, 2009).

Yazında yaşam doyumu ile farklı değişkenler arasındaki ilişkileri ele alan bazı araştırmalar yürütülmüştür. Yaşam doyumunun; iş doyumu (Tait vd., 1989; Özdemir, 2015), sosyal destek (Adams, King \& King, 1996; Altıparmak, 2009; Topkaya \& Kavas, 2015), duygusal zeka (Extremera \& 
Fernadez-Berrocal, 2005; Palmer, Donaldson \& Stough, 2002) ve öz-yeterlilik (Telef, 2011) ile pozitif yönlü bir ilişkisi olduğu görülmektedir. $\mathrm{Bu}$ durumun aksine yaşam doyumunun; iş-aile, aile-iş çatışması (Ellen \& Cynthia, 1998), tükenmişlik (Avşaroğlu vd., 2005; Demerouti, Bakker, Nachreiner \& Schaufeli, 2000), örgütsel sessizlik (Şimşek \& Aktaş, 2014), depresyon (Milevsky, Schlechter, Netter \& Keehn, 2007) ve işten ayrılma niyeti (Ghiselli, Lopa \& Bai, 2001) ile negatif yönlü bir ilişkisinin olduğu belirtilmektedir.

\section{4. İșe Bağlı Gerginlik}

İşe bağlı gerginlik ve stres sıklıkla birbiri yerine kullanılan kavramlar olarak bilinmekle beraber gerginlik, stresin organizma üzerinde yarattığı veya ortaya çıkardığı bozulma olarak ifade edilmektedir (Avc1, Öztürk, Azaklı \& Çekinmez, 2016; Lazarus, 1993). Selye (1974) stresi, organizmanın her çeşit uyarıcıya veya değişime karşı verdiği özel olmayan, siradan tepkisi olarak ifade etmektedir (Pehlivan, 1995). Stres, kişinin çevresindeki fiziksel veya psikolojik uyarıcılara karşı organizmanın uyumu sağlamak amaciyla verdiği bedensel ve ruhsal tepki ve gerilim halidir (Aydın, 2004). Stres, bireylerin tüm yaşamları boyunca karşı karşıya kaldıkları bir olgu olup, çeşitli çevresel uyarıcıların vücudun bedensel ve ruhsal durumunu tehdit etmesi ve zorlaması sonucunda ortaya çıkan bir durumdur (Baltaş \& Baltaş, 2009). Çağın hastalığı olarak bilinen stres, her ortamda kendini göstermektedir. İşe bağlı gerginliğin en önemli öncülü olan stresin, örgütsel sebep ve sonuçları ile bireysel sebep ve sonuçları farklı olabilmektedir (Özcan, Ünal \& Çakıc1, 2014).

İşe bağlı gerginlik, bireylerin iş ile ilgili değişiklikleri tehdit ya da tehlike olarak algıladığı, örgüt tarafından uygun ortam sağlandığında uyum gösterdiği, sağlanmadığında ise kendisini tehdit altında hissettiği olayların bütünüdür (Özyer, 2016). İşe bağlı gerginlik, iş ortamında stres yaratan durumların sıklığı veya fazlalığ 1 , gerek iş ortamının mevcut şartları gerekse de bireyin özellikleri ve/veya yapısının etkileşimi sonucu ortaya çıkmaktadır (Açık vd., 2016). Örgüt içindeki olumsuz çalışma koşulları (aşırı iş yükü, rol belirsizliği, rol çatışması, ergonomik nedenler, stres vb.), çalışanlar arasındaki iletişimsizlik ve çatışma gibi sorunlar bireylerde gerilime neden olabilmektedir (Tel, Aydın, Karabey, Vergi \& Akay, 2012). İşe bağlı gerginlik, bireyin çevresindeki uyarıcılara karşı gösterdiği psikolojik tepkilerdir. $\mathrm{Bu}$ tepkilerin nedeni olarak iki önemli kuram öne sürülmektedir. Birincisi çevresel etkenler kuramına göre, işe bağlı gerginliğin sebebi işle ilgili örgütsel şartlar iken, kişisel faktörler kuramına göre ise, kişisel özelliklerin bireylerin çevresel uyarıcıları algılamaları ve tepki vermeleri olarak belirtilmektedir (Yürür \& Keser, 2010).

Yazında, işe bağlı gerginlik ile farklı değişkenler arasındaki ilişkileri ele alan bazı araştırmalar yürütülmüştür. İşe bağlı gerginlik; iş doyumunu (Berg \& Hallberg, 1999; Koşucu, Göktaş \& Yıldız, 2017) ve iş performansını (Dunk, 1993; Emsley, 2003; Lau, Low \& Eggleton, 1995) azaltmakta, rol çatışması ve rol belirsizliğini (Başçı, Özyurda \& Y1lmazer, 2016), duygusal tükenmeyi (Sünter vd., 2006; Yürür \& Keser, 2010), işten ayrılma niyetini (Barnes, Agago \& Coombs, 1998), örgütsel güveni (Leat \& El-Kot, 2009; Ross, 1994) ve fiziksel rahatsılıkları (Wilkins \& Beaudet, 1998) arttırmaktadır.

\subsection{Değişkenler Arasındaki İlişsiler}

Çalışma yaşamında bireylerin iş ile ilgili duygusal iyilik halinde (iş doyumu, duygusal tükenme ve duyarsızlaşma) yapılan işin özellikleri belirleyici olabilmektedir (Ceyhan \& Siliğ, 2005). Bireylerin iş yaşamına karşı duygusal tepkisini ifade eden iş doyumu işe karşı geliştirilen tutuma dayanmakta ve işe ilişkin faktörler (işin kendisi, koşulları, getirisi vb.) iş doyumu üzerinde etkili olmaktadır (Çakıcı vd., 2013). İşe karşı geliştirilen duygusal tepkiler bazı durumlarda ise olumsuz sonuçlar ortaya çıkarmaktadır. Örneğin, iş yükü arttıkça çalışanlar kendilerini daha çok tükenmiş hissetmekte ve yaptıkları işe karşı negatif tutumlar benimsemeye yönelmektedir (Tayfur \& Arslan, 2012). Dolayısıyla, aşırı iş yükü altında çalışan bireylerin iş doyumlarının da düşük olması beklenmektedir. Nitekim, Keser (2006), çağrı merkezi çalışanları ile yaptığı araştırmasında, aşırı iş yükü altında görev yapan çalışanların iş doyumlarının düşük olduğunu belirtmektedir. Aynı şekilde Cole, Panchanadeswaran ve Daining (2004), Chou ve Robert (2008) ile Jones, Chonko, Rangarajan ve Roberts (2007) çalışmalarında, bireylerin iş yükleri arttıkça işten sağladıkları doyumun azaldığı yani değişkenler arasında negatif bir ilişkinin olduğunu vurgulamaktadır. Bu bağlamda kuramsal çerçeve ve yapılan görgül araştırmalara dayanılarak aşırı iş yükü ve iş doyumu arasındaki ilişkiye yönelik aşağıdaki hipotez ortaya konulmuştur.

Hipotez 1: Aşırı iş yükü iş doyumunu negatif ve anlamlı olarak etkiler.

İş doyumu, bireyin iş odaklı beklentilerine ilişkin bir değerlendirme sağlamaktadır. Oysa, bireyin iş dışındaki beklentilerinin de onun mutluluğunu etkileyeceği açıktır ve bu yöndeki incelemeler iş doyumu ile oldukça iç içe olan yaşam doyumu kavramını karşımıza çıkarmaktadır. Yaşam doyumu, belli bir durum karşısında değil genel 
olarak bütün yaşam karşısındaki doyumu ifade etmektedir (Yiğit, 2012). Bu açıdan ele alındığında, yaşam doyumu, kişinin, iş, boş zaman ve diğer iş dışı zaman olarak açıklanan yaşama ilişkin duygusal tepkisi olarak açıklanmaktadır (Keser, 2005). Yaşamın tüm boyutları dikkate alındığında, bireyin işi, ailesi, sağlık, para, yakın çevre gibi birçok faktör yaşam doyumunu sağlayan alanlar olarak düşünülebilir (Recepoğlu, 2013). Dolayısıyla iş doyumunu negatif olarak etkilemesi beklenen aşırı iş yükünün bu çalışmanın diğer bir değişkeni olan yaşam doyumunu da negatif yönde etkilemesi beklenmektedir. De Cuyper ve De Witte (2006) kadrolu ve geçici çalışanlar ile gerçekleştirdikleri araştırmalarında, kadrolu çalışanların aşırı iş yükü algılamalarının yaşam doyumları üzerinde negatif bir etkisinin olduğunu vurgulamaktadır. Goh, Ilies ve Wilson (2015) çalışmalarında alan yazını ile aynı doğrultuda aşırı iş yükünün çalışanların yaşam doyumları üzerinde negatif bir etkisinin olduğunu belirmektedirler. Aynı doğrultuda Çelik (2016) de çalışmasında, aşırı iş yükünün yaşam doyumu üzerinde olumsuz bir etkisinin olduğunu vurgulamaktadır. Bu bağlamda kuramsal çerçeve ve yapılan görgül araştırmalara dayanılarak aşırı iş yükü ve yaşam doyumu arasındaki ilişkiye yönelik aşağıdaki hipotez ortaya konulmuştur.

Hipotez 2: Aşırı iş yükü yaşam doyumunu negatif ve anlamlı olarak etkiler.

İş yükünün miktarı bireyin sağlıklı çalışma performansını etkileyen önemli bir faktördür (Baltacı, 2017). İş yükü arttıkça birey üzerinde stres ve yorgunluk oluşacaktır (Turgut, 2011). Aşırı iş yükünün birey üzerindeki bu etkileri yazında çeşitli araştırmalarda da vurgulanmaktadır. Lundberg ve Frankenhaeuser (1999) kadın ve erkek üst düzey yöneticiler ile gerçekleştirdikleri çalışmalarında, aşırı iş yükünün kadın çalışanlarda daha fazla işten kaynaklanan gerilime neden olduğunu belirtmektedirler. Krantz, Berntsson ve Lundberg (2005) ise çalışmalarında, aşırı iş yükünün bireyde strese bağlı gerilim yaratığını ortaya koymaktadırlar. Bu bağlamda kuramsal çerçeve ve yapılan görgül araştırmalara dayanılarak aşırı iş yükü ve işe bağlı gerginlik arasındaki ilişkiye yönelik aşağıdaki hipotez ortaya konulmuştur.

Hipotez 3: Aşırı iş yükü işe bağlı gerginliği pozitif ve anlamlı olarak etkiler.

İşe bağlı gerginlik, bireyleri çalışma hayatında strese, yorgunluğa, mutsuzluğa, tükenmeye ve doyumsuzluğa düşüren önlem alınması gereken bir konudur. Bireylerde işe bağlı gerginlik düzeyi yükseldikçe iş doyum düzeyleri de buna bağlı olarak azalmaktadır (Efeoğlu \& Özgen, 2007; Özkaya, Yakın \& Ekinci, 2008; Yüksel, 2003).
Ancak bireylerin işe bağlı gerginlik düzeyleri sadece iş hayatındaki doyumsuzluğu değil, iş hayatının bir devamı olarak nitelendirilebilecek genel yaşam doyumunu da olumsuz olarak etkileyebilmektedir (Koşucu vd., 2017). Yazında yapılan araştırmalarda da işe bağlı gerginliğin örgütsel bir çıktı olarak iş doyumunu (Başçı vd., 2016; Revicki, May \& Whitley, 1991) ve yaşam doyumunu (Gürel \& Altunoğlu, 2016) azalttı̆̆ sonucu üzerinde durulmaktadır. $\mathrm{Bu}$ bağlamda kuramsal çerçeve ve yapılan görgül araştırmalara dayanılarak işe bağlı gerginliğin iş doyumu ve yaşam doyumu ile ilişkisinin tespit edilmesine yönelik aşağıdaki hipotezler ortaya konulmuştur

Hipotez 4: İşe bağlı gerginlik iş doyumunu negatif ve anlamlı olarak etkiler.

Hipotez 5: İşe bağlı gerginlik yaşam doyumunu negatif ve anlamlı olarak etkiler.

Aşırı iş yükü, çalışanlar ve çevreleri üzerinde olumsuz etkiler doğurmaktadır. İş ortamındaki deneyimler bireyin yalnızca iş yaşamına değil, iş dışına da taşınmaktadır. Dolayısıyla yoğun iş yükü, bireyin iş ya da yaşam karşısındaki duygusal tepkilerine olumsuz yansıyabilmektedir (Çakıcı vd., 2013). İş ve yaşam doyumu olarak kavramsallaştırılan ve birbiri ile iç içe geçmiş olan bu duygusal tepkiler, güdülenme temelinde açıklanmaktadır. Güdülenme kuramlarından Beklenti Kuramı, bireylerin işten beklentileri ve işten elde ettikleri kazanımların karşılaştırılmasının sonucunda bireyin harekete geçeceğine odaklanmakta ve işin nitelikleri ile bireyin beklentileri arasında uyum yakalandığında iş doyumu ortaya çıkmaktadır (Dikmen, 1995). Aşırı iş yükü karşısında beklentileri karşılanmadığında işe bağlı gerginlik deneyimlerinin artması beklenen bireylerin doyum düzeyinin ise azalacağ 1 düşünülmektedir. Diğer bir güdülenme kuramı olarak Eşitlik Teorisi bireylerin iş ortamındaki adalet algılarına yönelik olarak denklik arayışlarında girdi ve çıktı ilişkisindeki sorgulamalarını açıklamakta ve denge durumuna dair algının bireyde doyum sağladığını açıklamaktadır (Ertürk \& Keçecioğlu, 2012). Aşırı iş yükü bireyin bu dengeye ilişkin inancını sarsmakta iken aşırı iş yükü altında ezilen birey üzerinde iş kaynaklı gerilimin oluşması ve doyumun da azalması beklenmektedir. Ayrıca yazında yer alan araştırmalarda aşırı iş yükü ile iş ve yaşam doyumu arasında negatif yönlü bir iliş̧inin (Cole vd., 2004; Goh vd., 2015), aşırı iş yükü ile işe bağlı gerginlik arasında pozitif yönlü bir ilişkinin (Krantz vd., 2005), işe bağlı gerginlik ile iş ve yaşam doyumu arasında negatif yönlü bir ilişkinin (Aslan, Alparslan, Aslan, Kesepera \& Ünal, 1998; Gürel \& Altunoğlu, 2016) olduğu 
görülmektedir. Ancak yazın taramasında aşırı iş yükünün iş ve yaşam doyumu üzerindeki etkisinde işe bağlı gerginliğin aracı rolünü inceleyen çalışmaya rastlanmamıştır. Kuramsal çerçeve ve yapılan görgül araştırmalara dayanılarak aşırı iş yükünün iş ve yaşam doyumunu negatif yönde ve işe bağlı gerginliği pozitif yönde etkileyebileceği, işe bağlı gerginliğin ise iş ve yaşam doyumu üzerinde negatif bir etkisinin olabileceği düşünüldüğünde aşırı iş yükü ile iş ve yaşam doyumu arasındaki ilişkide işe bağlı gerginliğin aracılık rolünün olup olmadığı araştırılmaya değer bulunmuştur. $\mathrm{Bu}$ bağlamda araştırmanın temel amacı bu kurgu üzerine odaklanarak söz konusu aracılık ilişkisinin tespit edilmesinde aşağıdaki hipotezler ortaya konulmuştur.

Hipotez 6: Aşırı iş yükünün iş doyumu üzerindeki etkisinde işe bağlı gerginliğin aracı rolü vardır.

Hipotez 7: Aşırı iş yükünün yaşam doyumu üzerindeki etkisinde işe bağlı gerginliğin aracı rolü vardir.

\section{YÖNTEM}

\subsection{Araștırmanın Amacı ve Önemi}

Araştırmanın temel amacı, çalışanların aşırı iş yükü algılamalarının iş ve yaşam doyumları üzerindeki etkisinde işe bağlı gerginliğin aracı rolünün incelenmesidir. İșten yeteri kadar doyum sağlayan çalışanlar bu doyumlarını iş harici yaşamlarına da taşırlar. Ancak bu durum her zaman böyle olmayabilir. Çünkü örgüt içindeki bazı olumsuz durumlar buna izin vermeyebilir. Aşırı iş yükü ve işe bağlı gerginlik bu olumsuz durumlara örnek olarak verilebilir. Aşırı iş yükü ve buna bağlı olarak oluşan gerginlik ve stres hali çalışanların işlerinden sağladıkları doyumu dolayısıyla yaşam doyumunu olumsuz olarak etkileyebilir. Bu bağlamda örgütsel amaçlarına ulaşmak isteyen örgütler, bu olumsuz faktörlerin ortadan kaldırılması veya azaltılması konusunda gerekenleri yapmak durumundadirlar. Ayrıca bu çalışma ile değişkenler arasındaki aracılık rolünün ortaya çıkartılması ve yazın taramasında rastlanmayan bu ilişki ortaya konularak yazına bu konuda katkı sağlamanın hedeflenmesi araştırmanın önemini arttırmaktadır.

\subsection{Araştırmanın Evreni ve Örneklemi}

Araştırmanın evreni, Malatya ilinde faaliyetlerini sürdüren bir tekstil işletmesinde görev yapan 1136 çalışandan oluşmaktadır. Araştırmada tüm evrene ulaşma imkânı olmadığından kolayda örnekleme yöntemi kullanılmıştır. Toplam 1136 çalışandan oluşan araştırma evreninin $\alpha=.05$ güven düzeyi ve \pm .05 hata düzeyinde temsil edilebilmesi için en az 288, $\alpha=.01$ güven düzeyi ve \pm .01 hata düzeyinde temsil edilebilmesi için en az 420 çalışandan oluşan bir örneklem grubuna ihtiyaç duyulmaktadır (Gürbüz \& Şahin, 2016). Bu bağlamada, işletmeye gönderilen 600 anketten geri dönüşümü sağlanan 528 anket formu (\%88 yanıtlanma oranı) araştırma evrenini $\alpha=.01$ güven düzeyinde temsil edecek niteliktedir.

\subsection{Araștırmanın Anket Formu ve Kullanılan Ölçekler}

Araştırmada verilerin güvenilir bir şekilde toplanabilmesi ve araștırma hipotezlerinin test edilebilmesi amacıyla birincil veri toplama kaynağı olan anket yönteminden yararlanılmıştır. Anket formunda; katılımcıların aşırı iş yükü düzeylerini ölçmek için “Aşırı İş Yükü Ölçeğì”, iş doyumlarını ölçmek için "İş Doyumu Ölçeği", yaşam doyumlarını ölçmek için "Yaşam Doyumu Ölçeği" ve işe bağlı gerginlik düzeylerini ölçmek için ise "İşe Bağlı Gerginlik Ölçeği” kullanılmıştır.

Katılımcıların aşırı iş yükü düzeyini ölçmek amaciyla; Peterson, Smith, Akande ve Ayestaran (1995) tarafından geliştirilen, Türkçe'ye Derya (2008) tarafindan uyarlanan, Çelik ve Çıra (2013), Çuhadar ve Gencer (2016) ve Tayfur ve Arslan (2012) tarafından çalışmalarında yararlanılan, geçerliliği ve güvenilirliği kanıtlanmış "Aşırı İş Yükü Ölçeği” kullanılmıştır. Ölçek tek boyut 11 maddeden oluşmaktadır. Ölçekte, "İş yüküm oldukça ağır." ve "Yaptığım iş bilgi ve beceri seviyemin üzerindedir." şeklinde ifadeler yer almaktadır. Ölçeğin puanlaması, 5'li Likert ölçeğine uygundur. $\mathrm{Bu}$ araştırmada, ölçeğin güvenilirlik analizi Cronbach Alfa katsayısı ile incelenmiş olup, değeri \%88.4 $(\alpha=88.4)$ olarak belirlenmiştir. Aşırı iş yükü ölçeğinin geçerliliğini test etmek için AMOS paket programı kullanılmıştır. Gerçekleştirilen doğrulayıcı faktör analizine ait bulgular Tablo 1'de sunulmuştur (Bkz Tablo 1). Bulgulara göre, ölçeğin Derya (2008) tarafindan Türkçe'ye uyarlanan ölçek ile iyi bir uyum sağladığı belirtilebilir. Sonuç olarak 11 madde ve tek boyutlu aşırı iş yükü ölçeğinin geçerliliği doğrulanmıştır.

Katılımcıların iş doyumlarını ölçmek amacıyla; Brayfield ve Rothe (1951) tarafindan geliştirilen, Türkçe'ye Bilgin (1995) tarafindan uyarlanan, Keser (2006), Yürür ve Keser (2010), Kanbur vd. (2017) ve Cindiloğlu, Polatcı, Özçalık ve Gültekin (2017) tarafindan çalışmalarında yararlanılan, geçerliliği ve güvenilirliği kanıtlanmış "İş Doyumu Ölçeği” kullanılmıştır. Ölçek tek boyut 5 maddeden oluşmaktadır. Ölçekte, "İşimi severek yaparım.” ve "Mevcut işimden çok memnunum." şeklinde 
Tablo 1: Așırı İș Yükü Ölçeğinin Doğrulayıcı Faktör Analizi

\begin{tabular}{lcccc}
\hline Model & $\mathbf{X}^{2} / \mathbf{d f}$ & RMSEA & GFI & CFI \\
\hline AíYÖ (Tek Faktör) & 2,86 & 0,06 & 0.967 & 0.997 \\
\hline İyi Uyum* & $\leq 3$ & $\leq .08$ & $\geq 90$ & $\geq 90$ \\
\hline
\end{tabular}

* Schermelleh-Engel, Moosbrugger \& Müller, (2003)

Tablo 2: İș Doyumu Ölçeğinin Doğrulayıcı Faktör Analizi

\begin{tabular}{lcccc}
\hline Model & $\mathbf{X}^{2} / \mathbf{d f}$ & RMSEA & GFI & CFI \\
\hline İDÖ (Tek Faktör) & 2,33 & 0,05 & 0,997 & 0,992 \\
\hline İyi Uyum* & $\leq 3$ & $\leq .08$ & $\geq 90$ & $\geq 90$ \\
\hline
\end{tabular}

* Schermelleh-Engel vd. (2003)

Tablo 3: Yaşam Doyumu Ölçeğinin Doğrulayıcı Faktör Analizi

\begin{tabular}{lcccc}
\hline Model & $\mathbf{X}^{2} / \mathbf{d f}$ & RMSEA & GFI & CFI \\
\hline YDÖ (Tek Faktör) & 1,485 & 0,03 & 0,997 & 0,999 \\
\hdashline İyi Uyum* & $\leq 3$ & $\leq .08$ & $\geq 90$ & $\geq 90$ \\
\hline
\end{tabular}

* Schermelleh-Engel vd. (2003)

ifadeler yer almaktadır. Ölçeğin puanlaması, 5'li Likert ölçeğine uygundur. Bu araştırmada, ölçeğin güvenilirlik analizi Cronbach Alfa katsayısı ile incelenmiş olup, değeri \%77.4 ( $\alpha=77.4)$ olarak belirlenmiştir. İş doyumu ölçeğinin geçerliliğini test etmek için AMOS paket programı kullanılmıştır. Gerçekleştirilen doğrulayıcı faktör analizine ait bulgular Tablo 2'de sunulmuştur. Bulgulara göre, ölçeğin Bilgin (1995) tarafindan Türkçe'ye uyarlanan ölçek ile iyi bir uyum sağladığ belirtilebilir. Sonuç olarak 5 madde ve tek boyutlu iş doyumu ölçeğinin geçerliliği doğrulanmıştır. (Bkz. Tablo 2)

Katılımcıların yaşam doyumlarını ölçmek amacıyla; Diener ve arkadaşları (1985) tarafindan geliștirilen, Türkçe'ye Köker (1991) tarafindan uyarlanan, Ünal, Karlıdağ ve Yoloğlu (2001), Avşaroğlu vd. (2005), Çeçen (2008), Sapmaz ve Doğan (2012), Akgündüz (2013), Kanbur ve Erol (2017) tarafindan çalışmalarında yararlanılan, geçerliliği ve güvenilirliği kanıtlanmış "Yaşam Doyumu Ölçeği" kullanılmıştır. Ölçek tek boyut 5 maddeden oluşmaktadır. Ölçekte, "Hayatımdan memnunum." ve "Hayatımda sahip olmak istediğim her şeye sahibim." şeklinde ifadeler yer almaktadır. Ölçeğin puanlaması, 7'li Likert ölçeğine uygundur. $\mathrm{Bu}$ araştırmada, ölçeğin güvenilirlik analizi Cronbach Alfa katsayısı ile incelenmiş olup, değeri \%86.7 $(\alpha=86.7)$ olarak belirlenmiştir. Yaşam doyumu ölçeğinin geçerliliğini test etmek için AMOS paket programı kullanılmıştır. Gerçekleştirilen doğrulayıcı faktör analizine ait bulgular Tablo 3'te sunulmuştur. Bulgulara göre, ölçeğin Köker (1991) tarafindan Türkçe'ye uyarlanan ölçek ile iyi bir uyum sağladığı belirtilebilir. Sonuç olarak 5 madde ve tek boyutlu yaşam doyumu ölçeğinin geçerliliği doğrulanmıştır. (Bkz. Tablo 3) 
Katılımcıların işe bağlı gerginlik düzeylerini ölçmek amacıyla; Revicki ve arkadaşları (1991) tarafindan geliştirilen, Türkçe'ye Aslan ve arkadaşları (1998) tarafından uyarlanan, Arıkan ve Karabulut (2004), Yürür ve Keser (2010), Başçı ve arkadaşları (2016), Açık ve arkadaşları (2016) ve Koşucu ve arkadaşları (2017) tarafindan çalışmalarında yararlanılan, geçerliliği ve güvenilirliği kanıtlanmış “İşe Bağlı Gerginlik Ölçeği”" kullanılmıştır. Ölçeğin orijinali 18 madde tek boyut olup, Aslan ve arkadaşları (1998) çalışmalarında bir maddenin ölçeğin madde test korelasyonunu oldukça düşürdüğü ve bundan sonraki çalışmalarda ölçeğin, bu madde ölçekten çıkartılarak kullanılmasının uygun olacağını belirtmiş̧lerdir. Bu bağlamda araştırmada kullanılan ölçek tek boyut ve 17 maddeden oluşmaktadır. Ölçekte, "İşyerimde sıklıkla kullanıldığımı hissederim." ve "İşimde hak ettiğim takdiri görmediğimi düşünüyorum." şeklinde ifadeler yer almaktadır. Ölçeğin puanlaması, 5'li Likert ölçeğine uygundur. $\mathrm{Bu}$ araştırmada, ölçeğin güvenilirlik analizi Cronbach Alfa katsayısı ile incelenmiş olup, değeri \%86.1 $(\alpha=86.1)$ olarak belirlenmiştir. İşe bağlı gerginlik ölçeğinin geçerliliğini test etmek için AMOS paket programı kullanılmıştır. Gerçekleştirilen doğrulayıcı faktör analizine ait bulgular Tablo 4'te sunulmuştur. (Bkz. Tablo 4)

Bulgulara göre, ölçeğin Aslan ve arkadaşları (1998) tarafindan Türkçe'ye uyarlanan ölçek ile iyi bir uyum sağladığı belirtilebilir. Sonuç olarak 17 madde ve tek boyutlu işe bağlı gerginlik ölçeğinin geçerliliği doğrulanmıştır.

\section{BULGULAR}

$\mathrm{Bu}$ bölümde, araştırmada yer alan değişkenler arasındaki ilişkileri ve aracılık etkisini göstermek için iki araştırma modeli ortaya konmuştur. Bu iki modeli doğrulamak üzere değişkenler arasındaki ilișkiyi ortaya koymak amacıyla korelasyon analizi (Bkz. Tablo 5) ve aracılık rolünü test etmek için ise hiyerarşik regresyon analizi (Bkz. Tablo 6-7) kullanılmıştır.

\subsection{Korelasyon Analizi}

Aşırı iş yükü, iş doyumu, yaşam doyumu ve işe bağlı gerginlik değișkenleri arasındaki ilișkiyi ortaya koymak amaciyla yapılan korelasyon analizi ile değişkenlere ait ortalama ve standart sapma değerleri Tablo 5 'te sunulmaktadır. (Bkz. Tablo 5)

Tablo 5 'te yer alan, aşırı iş yükü, iş doyumu, yaşam doyumu ile işe bağlı gerginlik arasındaki korelasyon analizine ilişkin bulgular incelendiğinde; aşırı iş yükü ile iş doyumu ( $\mathrm{r}=-, 435$; $\mathrm{p}<, 01)$ ve yaşam doyumu $(\mathrm{r}=-, 175 ; \mathrm{p}<, 01)$ arasında anlamlı ve negatif, işe bağlı gerginlik ile $(\mathrm{r}=, 233$; $\mathrm{p}<, 01)$ arasında anlamlı ve pozitif bir ilişkinin olduğu görülmektedir. İşe bağlı gerginlik ile iş

Tablo 4: İșe Bağlı Gerginlik Ölçeğinin Doğrulayıcı Faktör Analizi

\begin{tabular}{lcccc}
\hline Model & $\mathbf{X}^{2} / \mathbf{d f}$ & RMSEA & GFI & CFI \\
\hline YDÖ (Tek Faktör) & 2,68 & 0,056 & 0,945 & 0,939 \\
\hline İyi Uyum* & $\leq 3$ & $\leq .08$ & $\geq 90$ & $\geq 90$ \\
\hline
\end{tabular}

* Schermelleh-Engel vd. (2003)

Tablo 5: Değişkenler Arasındaki Korelasyon Analizi ve Bulguları

\begin{tabular}{|c|c|c|c|c|c|c|}
\hline Değişkenler & Ort. & SS. & 1 & 2 & 3 & 4 \\
\hline 1 Așırı İş Yükü & 3,28 & ,685 & 1 & & & \\
\hline 2 İş Doyumu & 2,86 & ,723 &,$- 435^{*}$ & 1 & & \\
\hline 3 Yaşam Doyumu & 3,10 & ,982 &,$- 175^{*}$ &, $426 *$ & 1 & \\
\hline 4 İşe Bağlı Gerginlik & 3,13 & ,712 & ,233* &,$- 206^{*}$ &,$- 132 *$ & 1 \\
\hline
\end{tabular}

$* \mathrm{p}<0.01$ düzeyinde anlamlıdır. 
doyumu $(\mathrm{r}=-, 206 ; \mathrm{p}<, 01)$ ve yaşam doyumu $(\mathrm{r}=$ $, 132 ; \mathrm{p}<, 01)$ arasında anlamlı ve negatif yönlü bir ilişkinin olduğu görülmektedir.

\subsection{Hiyerarşik Regresyon Analizi}

Aşırı iş yükünün iş ve yaşam doyumu üzerindeki etkisinde işe bağlı gerginliğin aracılık rolünü test etmek amaciyla SPSS paket programindan yararlanılarak hiyerarşik regresyon analizi kullanılmıştır. Aşırı iş yükünün iş doyumu üzerindeki etkisinde işe bağlı gerginliğin aracılık rolüne ilişkin $\mathrm{a}, \mathrm{b}, \mathrm{c}$ doğrusal regresyon ve $\mathrm{c} 1$ hiyerarşik regresyon yollarına (Model 1) ait bulgular Tablo 6'da sunulmaktadır. (Bkz. Tablo 6)

Tablo 6'da yer alan Model 1'e ait bulgular incelendiğinde; "a" yolu için beta katsayısı $(\beta)-, 435$ ve anlamlılık düzeyi $0,000(\mathrm{p}<0.01)$ olduğundan araştırmanın birinci hipotezi $\left(\mathrm{H}_{1}\right)$ desteklenmektedir $\left(R^{2}=18.9\right.$, Düz. $\left.R^{2}=18.8, F=122,875\right)$. "b" yolu için beta katsayısı $(\beta), 233$ ve anlamlılık düzeyi 0,000 $(\mathrm{p}<0.01)$ olduğundan araştırmanın üçüncü hipotezi $\left(\mathrm{H}_{3}\right)$ desteklenmektedir $\left(\mathrm{R}^{2}=5.4, \quad\right.$ Düz. $\mathrm{R}^{2}=5.3$, $F=30,284)$. "c" yolu için beta katsayısı $(\beta)-, 206$ ve anlamlılık düzeyi $0,000 \quad(\mathrm{p}<0.01)$ olduğundan araştırmanın dördüncü hipotezi $\left(\mathrm{H}_{4}\right)$ desteklenmektedir $\left(R^{2}=4.2\right.$, Düz. $\left.R^{2}=4.0, F=23.239\right)$. $\mathrm{Bu}$ bulgular 1şı̆̆ında Baron ve Kenny (1986) tarafindan hiyerarşik regresyonun (aracılık rolü) uygulanabilmesi için gereken koşulların sağlandığı görülmektedir. Bu bağlamda, aşırı iş yükü bağımsız değişkeni ile işe bağlı gerginlik aracı değişkeni modele birlikte katıldığında aşırı iş yükü bağımsız değişkeninin beta katsayısındaki $(\beta)$ değişime bakılmıştır. "c1" yolu hiyerarşik regresyon analizi incelendiğinde; aşırı iş yükü bağımsız değişkeninin beta katsayisinda $\left(\beta=-, 409 ; \quad p=, 000, \quad R^{2}=20.1\right.$, Düz. $\left.R^{2}=19.8, F=65,970\right)$ bir azalmanın olduğu, fakat işe bağlı gerginlik aracı değişkenin $(p=, 006)$ modele katılmasiyla tamamen ortadan kalkmadiğ görülmektedir. Tüm bu bulgular 1şı̆̆ında araştırmanın altıncı hipotezi $\left(\mathrm{H}_{6}\right)$ "kısmı aracılık etkisi vardır" olarak desteklenmektedir.

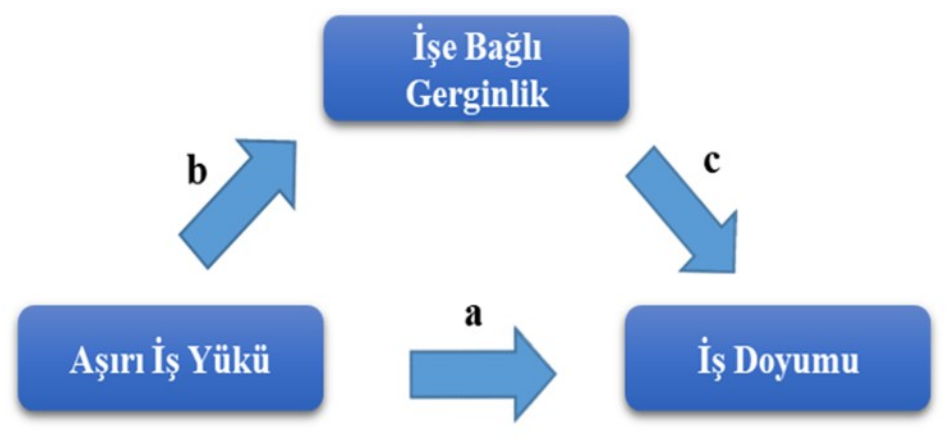

Model 1: Aşırı İş Yükünün İş Doyumu Üzerindeki Etkisinde İșe Bağlı Gerginliğin Aracı Rolü

Tablo 6: Model 1'e Ait Regresyon Analizi ve Bulguları

\begin{tabular}{|c|c|c|c|c|c|c|}
\hline Bağımsız/Aracı Değișken & $\begin{array}{l}\text { Bağımlı } \\
\text { Değișken }\end{array}$ & $\mathbf{R}^{2}$ & Düz.R ${ }^{2}$ & $\mathbf{F}$ & $\boldsymbol{\beta}$ & $\mathbf{p}$ \\
\hline Aşıırı İş Yükü & İş Doyumu &, 189 &, 188 & 122,875 &,- 435 &, $000 *$ \\
\hline Aşıırı İş Yükü & İşe Bağlı Gerginlik &, 054 &, 053 & 30,284 &, 233 &, $000^{*}$ \\
\hline İşe Bağlı Gerginlik & İ ş Doyumu &, 042 & .040 & 23,239 &,- 206 &, $000 *$ \\
\hline Așirı İş Yükü & & & & &,- 409 &, $000 *$ \\
\hline İşe Bağlı Gerginlik & İş Doyumu & 201 &, 198 & 65,970 &, 110 & $006^{*}$ \\
\hline
\end{tabular}

* $\mathrm{p}<0.01$ düzeyinde anlamlıdır.

Sobel $Z=2.479, p=0.013$ 
Aşırı iş yükünün yaşam doyumu üzerindeki etkisinde işe bağlı gerginliğgin aracılık rolüne ilişkin $\mathrm{d}$, e, f doğrusal regresyon ve $\mathrm{fl}$ hiyerarşik regresyon yollarına (Model 2) ait bulgular Tablo 7'de gösterilmektedir. (Bkz. Tablo 7)

Tablo 7'de yer alan Model 2'de ait bulgular incelendiğinde; "d" yolu için beta katsayısı $(\beta)$ ,175 ve anlamlılık düzeyi $0,000 \quad(\mathrm{p}<0.01)$ olduğundan araştırmanın ikinci hipotezi $\left(\mathrm{H}_{2}\right)$ desteklenmektedir $\left(R^{2}=3.1\right.$, Düz. $\left.R^{2}=2.9, F=16,699\right)$. "e" yolu için beta katsayısı $(\beta), 233$ ve anlamlılık düzeyi $0,000 \quad(\mathrm{p}<0.01)$ olduğundan araştırmanın üçüncü hipotezi $\left(\mathrm{H}_{3}\right)$ desteklenmektedir $\left(\mathrm{R}^{2}=5.4\right.$, Düz. $\left.\mathrm{R}^{2}=5.3, \mathrm{~F}=30,284\right)$. "f" yolu için beta katsayısı $(\beta)-, 132$ ve anlamlılık düzeyi $0,002 \quad(p<0.01)$ olduğundan araştırmanın beşinci hipotezi $\left(\mathrm{H}_{5}\right)$ desteklenmektedir $\left(R^{2}=1.8\right.$, Düz. $\left.R^{2}=1.6, F=9,381\right)$. $\mathrm{Bu}$ bulgular 1şı̆̆ında Baron ve Kenny (1986) tarafindan hiyerarşik regresyonun (aracılık rolü) uygulanabilmesi için gereken koşulların sağlandığı görülmektedir. Bu bağlamda, aşırı iş yükü bağımsız değişkeni ile işe bağlı gerginlik aracı değişkeni modele birlikte katıldığında aşırı iş yükü bağımsız değişkeninin beta katsayısındaki $(\beta)$ değişime bakılmıştır. "fl” yolu hiyerarşik regresyon analizi incelendiğinde; aşırı iş yükü bağımsız değişkeninin beta katsayısında $\left(\beta=-, 153 ; p=, 001, R^{2}=4.0\right.$, Düz. $\mathrm{R}^{2}=3.6, \mathrm{~F}=10,827$ ) bir azalmanın olduğu, fakat ișe bağlı gerginlik aracı değişkenin $(\mathrm{p}=, 028)$ modele katılmasıyla tamamen ortadan kalkmadığ görülmektedir. Tüm bu bulgular 1şı̆̆ında araştırmanın yedinci hipotezi $\left(\mathrm{H}_{7}\right)$ "kısmı aracılık etkisi vardır" olarak desteklenmektedir.

\section{Aşırı İş Yükü}
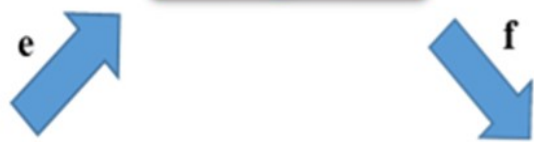

d

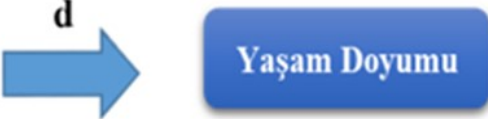

Model 2: Aşırı İş Yükünün Yaşam Doyumu Üzerindeki Etkisinde İşe Bağlı Gerginliğin Arac1 Rolü

Tablo 7: Model 2'ye Ait Regresyon Analizi ve Bulguları

\begin{tabular}{|c|c|c|c|c|c|c|}
\hline Bağımsız/Aracı Değișken & $\begin{array}{l}\text { Bağımlı } \\
\text { Değișken }\end{array}$ & $\mathbf{R}^{2}$ & Düz.R ${ }^{2}$ & $\mathbf{F}$ & $\boldsymbol{\beta}$ & $\mathbf{p}$ \\
\hline Aşırı İş Yükü & Yaşam Doyumu &, 031 &, 029 & 16,699 &,- 175 &, $000 *$ \\
\hline Aşırı İş Yükü & İşe Bağlı Gerginlik &, 054 &, 053 & 30,284 &, 233 &, $000 *$ \\
\hline İşe Bağlı Gerginlik & Yaşam Doyumu &, 018 &, 016 & 9,381 &,- 132 &, $002 *$ \\
\hline Aşır1 İş Yükü & & & & &,- 153 &, $001^{*}$ \\
\hline & Yaşam Doyumu &, 040 &, 036 & 10,827 & & $-\ldots$ \\
\hline İşe Bağlı Gerginlik & & & & &, 097 &, $028 * *$ \\
\hline
\end{tabular}

${ }^{*} \mathrm{p}<0.01 ;{ }^{* *} \mathrm{p}<0.05$ düzeyinde anlamlıdır.

Sobel $Z=2.047, p=0.040$ 


\section{TARTIŞMA ve SONUÇ}

Örgütsel görevlerde çalışanlara farklı iş rolleri ve dolayısıyla farklı iş yükleri verilmektedir. Önemli olan bu iş yükleri ile çalışanın yetenek, beceri, bilgi ve tecrübesinin aynı doğrultuda ve adil olarak dağılmasıdır. $\mathrm{Bu}$ bağlamda örgütler, örgütsel iyileştirmeler yapabilmek, verimliliği arttırabilmek, çalışanlarının bilgi, tecrübe, yaratıcılık ve girişimciliklerinden yararlanabilmek için onlara yüklediği iş yükü düzeylerini kişisel özelliklerini de dikkate alarak analiz etmeli ve adil bir şekilde belirlemedirler (Bulut \& Soylu, 2009). Aşırı iş yüküne maruz kalan çalışanların işe bağlı gerginlik ve stres yaşamaları onların performansını olumsuz yönde etkilemektedir (Emsley, 2003). Aynı zamanda aşırı iş yükü ve buna bağlı gerginlik hali çalışanın işinden sağladığı doyumu ve bu doyumun devamı niteliğinde olan yaşamdan sağladığı doyumu da olumsuz olarak etkilemekte ve çalışanların negatif örgütsel davranış sergilemelerine sebep olmaktadır (Berg \& Hallberg, 1999). Örgütler; hedeflediği amaçlarına ulaşmak, rakipleri ile rekabet edebilmek, tüketicilerin isteklerine hızlı ve doğru cevap verebilmek için çalışan odaklı olmalı ve onların iş ve yaşam doyumlarını etkileyen iş yükü düzeylerinin adil olarak dağıtılmasını sağlamalıdır.

Araştırmanın temel amacı olan çalışanların aşırı iş yükü algılamalarının iş ve yaşam doyumları üzerindeki etkisinde işe bağlı gerginliğin aracı rolünün incelenmesi çerçevesinde araştırma hipotezleri oluşturulmuş, test edilmiş ve birtakım bulgulara ulaşılmıştır. Gerçekleștirilen regresyon analizi bulgularına göre, çalışanların aşırı iş yükü düzeylerinin onların iş doyumlarını negatif olarak etkilediği görülmektedir. Adams (1965) tarafından ortaya konulan eşitlik teorisine göre, çalışanlar örgüt içinde gösterdikleri çaba ve sergiledikleri performans karşıllı̆ında kendilerine ne derece adil davranıldığını (iș yükü miktarı, görev ve sorumluluk seviyeleri, ücret, kariyer olanağ 1 gibi) diğer çalışanlar ile karşılaştırırlar. Bu bağlamda çalışanlar, örgüt içinde üstlendikleri iş rolleri kapsamında kendilerine yüklenen veya verilen is yükü düzeylerinin tüm çalışanlar arasında adil olarak dağılmasını isterler. Bu konudaki adaletsizlik algılamaları onların iş performanslarını, moral ve motivasyon düzeylerini ve dolayısıyla işten sağladıkları doyumu düşürebilir. Yazında elde edilen bu araştırma bulgusu ile uyumlu çalışmalar bulunmaktadır. Cole ve arkadaşları (2004), Keser (2006), Jones ve arkadaşları (2007), Chou ve Robert (2008) ile Altaf ve Awan (2011) çalışmalarında, aşırı iş yükü altında görev yapan çalışanların iş doyumlarının düşük olduğunu yani değişkenler arasında negatif bir ilişkinin olduğunu vurgulamaktadırlar. Araştırmanın diğer bir önemli bulgusuna göre; çalışanların aşırı iş yükü düzeyleri onların yaşam doyumlarını negatif olarak etkilemektedir. Çalışanların, iş yerinde yaptıkları işler ve yüklendikleri iş yükü düzeylerinin aşırı ve adaletsiz olması karşısında iş doyumları düşmektedir. Çalışanın işinden sağlayamadığı doyum onun iş harici yaşamını da olumsuz olarak etkilemektedir. Yaşam en genel anlamıyla iş ve iş harici geçirilen toplam zaman olarak anlamlandırılırsa, işte yaşanan olumsuzluk haliyle iş harici yaşamı da olumsuz olarak etkilemektedir. İs yerinde aşırı iş yükünün yarattığı stres, fiziksel ve bilişsel yorgunluk ve bitkinlik hali çalışanların yaşam kalitesini ve dolayısıyla yaşamdan sağladığı doyumu olumsuz olarak etkileyebilir. Yazında araştırmanın bu bulgusunu destekleyen çalışmalar yer almaktadır. De Cuyper ve De Witte (2006), Goh vd. (2015) ile Çelik (2016) çalışmalarında, aşırı iş yükünün çalışanların yaşam doyumları üzerinde negatif bir etkisinin olduğunu belirtmektedirler.

Araştırmanın diğer önemli bir bulgusuna göre; çalışanların aşırı iş yükü düzeyleri onların ișe bağlı gerginliğini pozitif yönde etkilemektedir. İșe bağl1 gerginliğin, belirsizlik ve yapılan iş miktarının (iş yükü) görece fazla olması veya algılanması sonucunda oluştuğu veya ortaya çıktığı belirtilebilir. Selye (1974) çalışmasında, stresin en belirgin ve önemli öncüllerinden birinin aşırı iş yükü olduğunu belirtmektedir. Zaman yetersizliğinden kaynaklanan baskı, birbirinden çok farklı, ağır ve yorucu ișlerin yapılması olarak ortaya çıkan aşırı iş yükü işe bağlı gerginliğe neden olan en önemli faktör olarak belirtilebilir. Aşırı iş yükünün neden olabileceği fiziksel, bilişsel ve duygusal yorgunluk altında ezilen çalışanların işe bağlı gerginlik yaşamaları onları örgüt içinde bazı istenmeyen ve önlenmesi gereken davranışlar (tükenmişlik, ișten ayrılma niyeti, performans düşüklüğü, tatminsizlik gibi) içerisine sokabilir. Dolayısıyla işe bağlı gerginliğin, öncüllerinden biri olarak aşırı iş yükü ile pozitif yönlü ilişkili olduğu görülmektedir. Yazında araştırma bulgusunu destekleyen çalışmalar bulunmaktadır. Krantz ve arkadaşları, (2005) ile Luk ve Shaffer (2005) çalışmalarında, işyerinde aşırı iş yüküne sahip olan çalıșanların işe bağlı gerginlik yaşadıkları ve bu durumun onların performanslarını olumsuz olarak etkilediğini vurgulamaktadırlar.

Araştırmanın diğer bir bulgusuna göre; çalışanların işe bağlı gerginlik düzeyleri onların iş ve yaşam doyumlarını olumsuz olarak etkilemektedir. İșe bağlı gerginliğin nedenleri (aşırı iş yükü, örgütsel adaletsizlik, tükenmişlik, belirsizlikler gibi) çalışanların işlerine karşı duyarlılıklarını ve doyum düzeylerini düşürmektedir. Yaşanan veya oluşan gerginliğin iş ve işin niteliğinden kaynaklanması 
çalışanların o işe karşı bakış açısını değiștirebilir ve işe karşı tatminsizliğe sürükleyebilir. Stresli, gergin ve tükenmiş olan çalışanların iş ve buna bağlı olarak yaşam doyumları olumsuz olarak etkilenmektedir. Yazında araştırma bulgusu ile uyumlu çalışmalar bulunmaktadır. Lee (1995), Yüksel (2003), Johnson, Cartwright, Donald, Taylor ve Millet (2005), Ahsan, Abdullah, Fie ve Alam (2009) ile Koşucu ve arkadaşları (2017) çalışmalarında, işe bağlı gerginlik yaşayan bireylerin iş ve yaşam doyumlarının düşük olduğunu vurgulamaktadırlar.

Araştırmanın son bulgusuna göre; çalışanların aşırı iş yükü düzeylerinin hem iş doyumu hem de yaşam doyumu üzerindeki etkisinde işe bağlı gerginliğin kısmi aracılık rolü vardır. Așırı iş yükünün iş ve yaşam doyumu üzerindeki negatif ve anlamlı etkisinde yine aşırı iş yükünün bir ardılı olan işe bağlı gerginliğin kısmı aracılık etkisinin olduğu görülmektedir. $\mathrm{Bu}$ bağlamda gerek aşırı iş yükü gerekse de işe bağlı gerginlik çalışanların iş ve yaşam doyumları üzerinde olumsuz bir etki yaratmakta ve önlem alınmadığ 1 takdirde çok farklı ve sorun oluşturabilecek örgütsel çıktılara neden olabilmektedir. Yazın taraması sonucunda aşırı iş yükünün iş ve yaşam doyumu üzerindeki etkisinde işe bağlı gerginliğin aracı rolünü inceleyen çalışmaya rastlanamamıştır. Dolayısıyla bu araştırma yazına bu yönü ile katkı sağlaması ve sonuçları itibariyle gelecekte yapılacak çalışmalara ve araştırmacılara 1 şı tutması açısından araştırmanın önemini arttırmaktadır.

Araştırmanın bulguları kapsamında uygulayıcılara ve araştırmacılara bazı önerilerde bulunulabilir. Örgütler, en kıymetli kaynağı olan çalışanlarını örgütsel hedefler doğrultusunda çalıştırmak, performanslarını, iş ve yaşam doyumlarını artırmak için iş yükü dağılımını adil bir şekilde yapmalı ve aşırı iş yükünün çalışanlar üzerindeki etkilerinin bilincinde olmalıdırlar. İş yükü analizleri gerçek veriler ışı ğında yapılmalı ve çalışanlar arasında işler adaletli bir şekilde dağıtılmalıdır. Çalışanlara kapasitesini aşacak işler verilmeyip, aksine özelliklerine, bilgisine ve yeteneklerine uygun işlerin verilmesi onların daha etkin ve verimli çalışmasına neden olabilir. Ayrıca örgütler; aşırı iş yükü, işe bağlı gerginlik ve bunun gibi olumsuz faktörlere karşı önlemlerini almalı ve gerekli örgütsel desteği sağlamalıdırlar. Örgütler için önemli olan bu kavramlar araştırmacılar için de son derece önemlidir. Araştırmacıların örgütsel çıktılara bu denli etkisi olan ilgili kavramları başka kavramlar ile ilişkilendirerek farklı örneklem grupları ile yürütülecek araştırmalarda tekrar test etmesi yazına katkı sağlayacaktır. Araştırmanın bir takım kısıtları bulunmaktadır. En önemli kısıtı, araştırmanın tek sektörde (tekstil) ve tek bir işletmedeki çalışanlar ile yürütülmesidir. Daha geniş, farklı sektör ve coğrafyalarda bulunan işletme çalışanları ile karşılaştırmalı olarak yapılacak bir araştırma ile daha açıklayıcı ve genellenebilir sonuçlara ulaşılabileceği değerlendirilmektedir. Diğer bir kısıt ise, araştırma verilerinin anket tekniği ile toplanması ve kullanılan ölçekler olarak belirtilebilir. 


\section{KAYNAKÇA}

Açık, Y., Yiğitbaş, Ç., Bulut, A., Deveci, E.S., Pirinçci, E., Oğuzöncül, F.A., Ozan, T.A., Demirbağ, C.B., Arın, E. \& Rahman, S. (2016). Acil sağlık çalışanlarında işe bağlı gerginlik, stresle başa çıkma yollarını kullanma durumu ve etkileyen faktörler. Türkiye Klinikleri J. Med. Sci., 36(1), 22-9.

Adams J. S. (1965). Inequity in social exchange. In Berkowitz L. (Ed.), Advances in experimental social psychology (Vol. 2, pp. 267-299). New York: Academic Press.

Adams, G. A., King, L. A. \& King, D. W. (1996). Relationships of job and family involvement, family social support, and work-family conflict with job and life satisfaction. Journal of Applied Psychology, 81(4), 411-420.

Ahsan, N., Abdullah, Z., Fie, D. Y. G. \& Alam, S. S. (2009). A study of job stress on job satisfaction among university staff in Malaysia: Empirical study. European Journal of Social Science 8(1), 121-131.

Akın, A. \& Yalnız, A. (2015). Yaşam memnuniyeti ölçeği (YMÖ) Türkçe formu: Geçerlik ve güvenirlik çalışması. Elektronik Sosyal Bilimler Dergisi, 14(54), $95-102$

Akgündüz, Y. (2013). Konaklama işletmelerinde iş doyumu, yaşam doyumu ve öz yeterlilik arasındaki ilișkinin analizi. Celal Bayar Üniversitesi Sosyal Bilimler Dergisi, 11(1), 180-204.

Altaf, A. \& Awan, A.M. (2011). Moderating affect of workplace spirituality on the relationship of job overload and job satisfaction. Journal Bus Ethics, 104, 93-99.

Altıparmak, S. (2009). Huzurevinde yaşayan yaşlı bireylerin yaşam doyumu, sosyal destek düzeyleri ve etkileyen faktörler. F. Ü. Sa ̆. Bil. Tip Dergisi, 23(3), 159-164.

Ardıç, K. \& Polatcı, S. (2009). Tükenmişlik sendromu ve madalyonun öbür yüzü: İşle bütünleşme. Erciyes Üniversitesi İktisadi ve İdari Bilimler Fakültesi Dergisi, 32, 21-46.

Arıkan, D. \& Karabulut, N. (2004). Hemşirelerde işe bağlı gerginlik ve bunu etkileyen faktörlerin belirlenmesi. Atatürk Üniversitesi Hemşirelik Yüksekokulu Dergisi, 7(1), 10-17.

Aslan, H., Alparslan, N., Aslan, O., Kesepera. C. \& Ünal, M. (1998). İşe bağlı gerginlik ölçeğinin sağlık alanında çalışanlarda geçerlik ve güvenirliği. Düşünen Adam Dergisi, 11(2), 4-8.

Avcı, G. G., Öztürk, G., Azaklı, N. \& Çekinmez, T. S. (2016). Özel bir grup hastanesinde çalışan hemşirelerin işe bağll gerginlik düzeylerinin ve stresle başa çıkma tarzlarının belirlenmesi. 4. Hemșirelikte Güncel Yaklaşımlar ve Sorunlar Kongresi, İzmir.

Avşaroğlu, S., Deniz, M. E. \& Kahraman, A. (2005). Teknik öğretmenlerde yaşam doyumu iş doyumu ve mesleki tükenmişlik düzeylerinin incelenmesi, Selçuk Üniversitesi Eğitim Fakültesi Dergisi, 14, 115-129.

Aydın, Ş. (2004). Örgütsel stres yönetimi. Dokuz Eylül Üniversitesi Sosyal Bilimler Dergisi, 6(3), 49-74.

Baltacı, A. (2017). İş yükü ve performans arasındaki ilișkiler: Ampirik bir araștırma. Sosyal Bilimler Enstitü Dergisi, 3(1), 101-121.

Baltaş, Z. \& Baltaş, A. (2009). Stres ve başa çıkma yollart. İstanbul: Remzi Kitabevi.

Barnes, L. B., Agago, M. O. \& Coombs, W.T. (1998). Effects of job-related stress on faculty intention to leave academia. Research in Higher Education, 39, 457-469.

Baron, M. R. \& Kenny, A. D. (1986). The moderatormediator variable distinction in social pyschological research. Conceptual, strategic and statistical considerations. Journal of Personality and Psychology, 51(6), 1173-1182.

Başçı, A. B. A., Özyurda, F. \& Yılmazer, G. (2016). Ankara Üniversitesi hemşirelerinde işe bağlı gerginlik düzeyi ve rol çatışması-rol belirsizliği durumu ve diğer etmenler. G.O.P. Taksim E.A.H. JAREN, 2(2), 51-58.

Berg, A. \& Hallberg, I. R. (1999). Effects of systematic clinical supervision on psychiatric nurses' sense of coherence, creativity, work related strain, job satisfaction: A prepost test design. Journal of Psychiatric and Mental Health Nursing, 6, 371-81.

Bilgin, N. (1995). Sosyal Psikolojide Yöntem ve Pratik Çalışmalar. İstanbul: Sistem Yayıncılık.

Brayfield, A. H. \& Rothe, H. F. (1951). An index of job satisfaction. Journal of Applied Psychology, 35, 307311.

Brown, S. P., Jones, E. \& Leigh, T. W. (2005). The attenuating effect of role overload on relationships linking self-efficacy and goal level to work performance. Journal of Applied Psychology, 90(5), 972-979.

Bruck, S. C., Allen, D. T. \& Spector, E. P. (2002). The relation between work-family conflict and job satisfaction: A finer-grained analysis. Journal of Vocational Behavior, 60, 336-353.

Bulut, K. \& Soylu, B. (2009). Öğretim üyelerinin iş yükü seviyelerinin bir analitik model ile değerlendirilmesi: mühendislik fakültesinde bir uygulama. Erciyes 
Üniversitesi Fen Bilimleri Enstitüsü Dergisi, 25(1-2), 150-167.

Cam, E. (2004). Çalışma yaşamında stres ve kamu kesiminde kadın çalışanlar. Uluslararası İnsan Bilimleri Dergisi, 1(1), 1-10.

Ceyhan, A. A. \& Siliğ, A. (2005). Banka çalışanlarının tükenmişlik düzeyleri ile uyum düzeyleri arasındaki ilişkiler. Sosyal Bilimler Dergisi, 2, 43-56.

Chang, C. E., Yang, H. \& Yu, T. (2017). Perceived interpersonal sources of life satisfaction in chinese and american students: Cultural or gender differences? The Journal of Positive Psychology, 12(4), 414-424.

Chou, J. R. \& Robert, A. S. (2008). Workplace support, role overload, and job satisfaction of direct care workers in assisted living. Journal of Health and Social Behavior, 49(2), 2008-222.

Cindiloğlu, M., Polatçı S., Özçalık, F. \& Gültekin, Z. (2017). İşyeri yalnızlığının iş ve yaşam tatminine etkisi: lider-üye etkileşiminin aracılık rolü. Ege Akademik Bakış, 17(2), 191-200.

Cole, D., Panchanadeswaran, S. \& Daining, C. (2004). Predictors of job satisfaction of licensed social workers. Journal of Social Service Research, 31(1), $1-12$.

Currivan, D. B. (1999). The causal order of job satisfaction and organizational commitment in models of employee turnover. Human Resource Management Review, 9(4), 495-524.

Çakıcı, A., Özkan, C. \& Akyüz, H. B. (2013). İş yükü yoğunluğunun, iş ve yaşam doyumuna etkisi üzerine otomotiv işletmelerinde bir araştırma. Cag University Journal of Social Sciences, 10(2), 1-27.

Çeçen, A. R. (2007). Üniversite öğrencilerinin cinsiyet ve yaşam doyumu düzeylerine göre sosyal ve duygusal yalnızlı düzeylerinin incelenmesi. Mersin Üniversitesi Ĕ̌itim Fakültesi Dergisi, 3(2), 180-190.

Çeçen, A. R. (2008). Üniversite öğrencilerinde yasam doyumunu yordamada bireysel bütünlük (tutarlılık) duygusu, aile bütünlük duygusu ve benlik saygısı. Eğitimde Kuram ve Uygulama, 4(1), 19-30.

Çelik, M. \& Çıra, A. (2013). Örgütsel vatandaşlık davranışının iş performansı ve işten ayrılma niyeti üzerine etkisinde aşırı iş yükünün aracılık rolü. Ege Akademik Baklş, 13(1), 11-20.

Çelik, M. (2016). Tükenmişlik yaşam doyumu ve iş yükü ilişkisi: Denizli'de faaliyet gösteren muhasebe meslek mensupları üzerinde bir araștırma. Süleyman Demirel Üniversitesi İktisadi ve İdari Bilimler Fakültesi Dergisi, 21(4), 1139-1152.
Çevik N. K. \& Korkmaz, O. (2014) Türkiye'de yaşam doyumu ve iş doyumu arasındaki ilişkinin iki değişkenli sıralı probit model analizi. Niğde Üniversitesi İktisadi ve İdari Bilimler Fakültesi Dergisi, 7(1), 126-145.

Çivitçi, A. (2009). İlköğretim öğrencilerinde yaşam doyumu; Bazı kişisel bilgiler ve ailesel özelliklerin rolü. Eğitim Fakültesi Dergisi, XXII (1), 29-52.

Çuhadar, M. \& Gencer, Z. (2016). Konaklama işletmelerinde çalışan işgörenlerin aşırı iş yükü ve örgütsel bağlılık algıları: Side ve Belek örneği. Süleyman Demirel Üniversitesi İktisadi ve İdari Bilimler Fakültesi Dergisi, 21(4), 1323-1346.

De Cuyper, N. \& De Witte, H. (2006). Autonomy and workload among temporary workers: Their effects on job satisfaction, organizational commitment, life satisfaction, and self-rated performance. International Journal of Stress Management, 13(4), 441-459.

Demerouti, E., Bakker, A. B., Nachreiner, F. \& Schaufeli, W. B. (2000). A model of burnout and life satisfaction among nurses. Journal of Advanced Nursing, 32, 454-464.

Derya, S. (2008). Crossover of work-family conflict: Antecedent and consequences of crossover process in dual-earner couples (Yayımlanmamış Doktora Tezi). Koç Üniversitesi, İstanbul.

Diener, E., Emmons, R. A., Larsen, R. J. \& Griffin, S. (1985). The satisfaction with life scale. Journal of Personality Assessment, 49, 71-75.

Diener, E. \& Lucas, R. E. (1999). Subjective well-being: Three decades of progress. Psychological Bulletin, 125(2), 276-303.

Diener, E. (2000). Subjective well-being: The science of happiness and a proposal for a national index. American Psychologist, 55(1), 34-43.

Dikmen, A. A. (1995). İş yaşamı ve yaşam doyumu ilişkisi. Ankara Üniversitesi Siyasal Bilgiler Fakültesi Dergisi, 3(50), 115-140.

Dorrian, J., Baulk, S. D. \& Dawson, D. (2011). Work hours, workload, sleep and fatigue in Australian Rail Industry employees. Applied Ergonomics, 42, 202209.

Dost, T. M. (2007). Üniversite öğrencilerinin yaşam doyumunun bazı değişkenlere göre incelenmesi, Pamukkale Üniversitesi Eğitim Fakültesi Dergisi, 22(132), 132-143.

Dunk, A. (1993). The effects of job-related tension on managerial performance in participative budgetary settings. Accounting. Organizations and Society, 18(7/8), 575-586. 
Efeoğlu, İ. F \& Özgen, H. (2007). İş-aile yaşam çatışmasının iş stresi, iş doyumu ve örgütsel bağlılık üzerindeki etkileri: İlaç sektöründe bir araştırma. Ç. $\ddot{U}$. Sosyal Bilimler Enstitüsü Dergisi, 16(12), 237-254.

Egan, T. M., Yang, B. \& Bartlett, K. R. (2004). The effectives of organizational learning culture and job satisfaction on motivation to transfer learning and turnover intention. Human Resource Development Quarterly, 15(2), 279-301.

Eğinli A. T. (2009). Çalışanlarda iş doyumu: kamu ve özel sektör çalışanlarının iş doyumuna yönelik bir araştırma. Atatürk Üniversitesi İktisadi ve İdari Bilimler Dergisi, 23, 35-53.

Ellen, E. K. \& Cynthia, O. (1998). Work-family conflict, policies, and the job-life satisfaction relationship: A review and directions for organizational behaviorhuman resources research. Journal of Applied Psychology, 83(2), 139-149.

Emsley, D. (2003). Multiple goals and managers' job-related tension and performance. Journal of Managerial Psychology, 18(4), 345-356.

Eren, E. (2004). Örgütsel davranış, yönetim psikolojisi. İstanbul: Beta Yayınevi.

Eroğlu, F. (2011). Davranış bilimleri. İstanbul: Beta Yayınevi.

Ertürk, E. \& Keçecioğlu, T. (2012). Çalışanların iş doyumları ile mesleki tükenmişlik düzeyleri arasındaki ilişkiler: Öğretmenler üzerine örnek bir uygulama. Ege Akademik Bakış, 12(1), 39-52.

Extremera, N. \& Fernadez-Berrocal, P. (2005). Perceived emotional intelligence and life satisfaction: predictive and incremental validity using the trait meta-mood scale. Personality and Individual Differences, 39, 937-948

Feather, N. T. \& Rauter, K. A. (2004). Organizational citizenship behaviours in relation to job status, job insecurity, organizational commitment and identification, job satisfaction and work values. Journal of Occupational and Organizational Psychology, 77, 81-94.

Ferreira, S., Akay, A., Cunado, J., Martinsson, P., Moro, M. \& Ningal, F. T. (2013). Life satisfaction and air quality in Europe, Ecological Economics, 88, 1-10.

Geurts, S. A. E, Kompier, M. A. J., Roxburgh, S. \& Houtman, I. L. D. (2003). Does work-home interference mediate the relationship between workload and well-being? Journal of Vocational Behavior, 63, 539-559.

Ghiselli, F. R., Lopa, M. J. \& Bai, B. (2001). Job satisfaction, life satisfaction, and turnover intent among food-service managers. The Cornell Hotel and Restaurant Administration Quarterly, 42(2), 28-37.
Goh, Z., Ilies, R. \& Wilson, S.K. (2015). Supportive supervisors improve employees' daily lives: The role supervisors play in the impact of daily workload on life satisfaction via work-family conflict. Journal of Vocational Behavior, 89, 65-73.

Greenglass, E. R., Burke, R. J. \& Riksenbaum, L. (2001). Workload and burnout in nurses. Journal of Community \& Applied Social Psychology, 11, 211215 .

Greenhaus, J. H., Parasuraman S., Granrose C.S., Rabinowitz, S. \& Beutell N.J. (1989) Sources of Work- Family Conflict Among Two Career Couples. J. Vocational Behaviour, 34, 133-153.

Gümüştekin, G. E. \& Öztemiz, B. (2005). Örgütlerde stresin verimlilik ve performansla etkileşimi. Çukurova Üniversitesi, Sosyal Bilimler Enstitüsü, 14(1), 271-288.

Gürbüz, S. \& Yüksel, M. (2008). Çalışma ortamında duygusal zekâ: İş performans1, iş tatmini, örgütsel vatandaşlık davranışı ve bazı demografik özelliklerle ilişkisi. Doğuş Üniversitesi Dergisi, 9(2), 174-190.

Gürbüz, S., Erkuş, A. \& Sığrı, Ü. (2010). İş tatmini ve iş performansının yeni öncülü: Temel benlik değerlendirmesi. Sosyal ve Beşerî Bilimler Dergisi, 2(1), 69-76.

Gürbüz, S. \& Şahin, F. (2016). Sosyal bilimlerde araştırma yöntemleri. Ankara: Seçkin Yayıncılık.

Gürel, B. B. E. \& Altunoğlu, A. E. (2016). İşkoliklik, iş stresi ve yaşam doyumu arasındaki ilişkilerin incelenmesi: Muğla ilinde bir araştırma. Journal of International Social Research, 9(42), 1431-1438.

Hancock, P. \& Verwey, W. (1997). Fatigue, workload and adaptive driver systems. Accident Analysis and Prevention, 29, 495-506.

Hellman, C. M. (1997). Job satisfaction and intent to leave. The Journal of Social Psychology, 137(6), 677689.

Johnson, S., Cooper, C., Cartwright, S., Donald, I., Taylor, P. \& Millet, C. (2005). The experience of work-related stress across occupations. Journal of Managerial Psychology, 20, 178-187.

Jones, E., Chonko, L., Rangarajan, D. \& Roberts, J. (2007). The role of overload on job attitudes, turnover intentions, and salesperson performance. Journal of Business Research, 60, 663-671.

Judge, T. A. \& Watanabe, S. (1993). Another look at the job satisfaction-life satisfaction relationship. Journal of Applied Psychology, 78(6), 939-948.

Judge, T. A., Bono, J. E., Erez, A. \& Locke, E. A. (2005). Core self-evaluations and job and life satisfaction: The role of self-concordance and goal 
attainment. Journal of Applied Psychology, 90(2), 257-268.

Kanbur, A. (2015). Does jop matter fort he happiness? Social and Sciences Research Review, 3(3), 156-166.

Kanbur, E., Kanbur, A. \& Özdemir, B. (2017). Psikolojik dayanıklılık ile örgütsel vatandaşlık davranışı arasındaki ilişkide iş doyumunun aracılık rolü: Havacılık sektöründe bir araştırma. İş ve Insan Dergisi, 4(2), 127-141.

Kanbur, E. \& Erol, A. (2017). Havacılık çalışanlarının yaşam doyumunun demografik değişkenler açısından değerlendirilmesi. Sosyal Ekonomik Araştırmalar Dergisi, 17(34), 50-64.

Keser, A. (2005). İş doyumu ve yaşam doyumu ilişkisisi: Otomotiv sektöründe bir uygulama. Çalışma ve Toplum, 4, 77-96.

Keser, A. (2006). Çağrı merkezi çalışanlarında iş yükü düzeyi ile iş doyumu ilişkisinin araştırılması. Kocaeli Üniversitesi Sosyal Bilimler Enstitüsü Dergisi, 11(1), 100-119.

Koşucu, N. S., Göktaş, B. S. \& Yıldız, T. (2017). Cerrahi ve dâhiliye servislerinde çalışan hemşirelerin işe bağlı gerginlik ve iş doyumu düzeylerinin değerlendirilmesi. Cukurova Medical Journal, 2(4), 675-681.

Köker, S. (1991). Normal ve sorunlu ergenlerin yaşam doyumu düzeylerinin karşılaştırılması (Yayınlanmamış Yüksek Lisans Tezi). Ankara Üniversitesi Sosyal Bilimler Enstitüsü, Ankara.

Krantz, G., Berntsson, L. \& Lundberg, U. (2005). Total workload, work stress and perceived symptoms in Swedish male and female white-collar employees. European Journal of Public Health, 15(2), 209-214.

Lau, C., Low, L. \& Eggleton, I. (1995). The impact of reliance on accounting performance measures on jobrelated tension and managerial performance: Additional evidence. Accounting, Organizations and Society, 20, 359-381.

Lazarus, R. S. (1993). From Psychological stress to the emotions: A history of changing outlooks. Annual Reviews Psycholgy, 44, 1-21.

Leat, M. \& El-Kot, G. (2009). Interpersonal trust at work, intrinsic motivation, work-related tension and satisfaction in Egypt. International Journal of Workplace Health Management, 2(2), 180-194.

Lee, S. M. (1995). The effect of job characteristics and personal factors on work stress, job satisfaction and turnover intention. Journal of Nurs. Acad. Soc. 25(4), 790-806.

Luhmann, M., Lucas, E. R., Eid, M. \& Diener, E. (2013). The prospective effect of life satisfaction on life events, Social Psychological and Personality Science, $4(1), 39-45$.

Lundberg, U. \& Frankenhaeuser, M. (1999). Stress and workload of men and women in high-ranking positions. Journal of Occupational Health Psychology, 4, 142-151.

Lok, P. \& Crawford, J. (2004). The effect of organisational culture and leadership style on job satisfaction and organisational commitment: A cross-national comparison. Journal of Management Development, 23(4), 321-338.

Luk, D. M. \& Shaffer M. A. (2005). Work and family domain stressors and support: Direct and indirect influences on work-family conflict. Journal of Occupational and Organisational Psychology, 78, 489-508.

Lum, L., Kervin, J., Clark, K., Reid, F. \& Sirola, W. (1998). Explaining nursing turnover intent: Job satisfaction, pay satisfaction, or organizational commitment? Journal of Organizational Behavior, 19(3), 305-320.

Maslach, C. \& Leiter, P.M. (1997). The truth about burnout, San Francisco: Jossey-Bass.

Milevsky, A., Schlechter, M., Netter, S. \& Keehn, D. (2007). Maternal and paternal parenting styles in adolescents: Associations with self-esteem, depression and life-satisfaction. Journal of Child and Family Studies, 16, 39-47.

Naima, B. (1998). Job satisfaction, stress and coping strategies among moroccan high school teachers. Mediterranean Journal of Educational Studies, 3(1), 3-33.

Neugarten, B. L., Havgghurst, R. J. \& Tobgn, S. S. (1961). The measurement of life satisfaction. Journal of Gerontology, 16, 134-143.

Oral, L. \& Köse, S. (2011). Hekimlerin duygusal emek kullanımı ile iş doyumu ve tükenmişlik düzeyleri arasındaki ilişkiler üzerine bir araştırma. Süleyman Demirel Üniversitesi, Iktisadi ve İdari Bilimler Fakültesi Dergisi, 16(2), 463-492.

Özcan, M. C., Ünal, A. \& Çakıcı, B. A. (2014). Sağlık çalışanlarında işe bağlı stres: Konya numune hastanesi saha çalışması. Aksaray Üniversitesi İktisadi ve İdari Bilimler Fakültesi Dergisi, 7(1), 125131.

Özdemir, A. A. (2015). İş tatmini, pozitif/negatif duygulanım ve yaşam tatmininin etkisi. Çalışma ve Toplum, 3, 47-62.

Özkaya, M. O., Yakın. V. \& Ekinci T. (2008). Stres düzeylerinin çalışanların iş doyumu üzerine etkisi Celal Bayar üniversitesi çalışanları üzerine ampirik 
bir çalışma. Yönetim ve Ekonomi Dergisi, 15(1), 163 180.

Özyer, Y. (2016). Cerrahi kliniklerinde çalışan hemşirelerde iş yükü alglsl, işe bağlı gerginlik ve tıbbi hata tutumları (Yayınlanmamış Yüksek Lisans Tezi). Ordu Üniversitesi, SBE, Ordu.

Palmer, B., Donaldson, C. \& Stough, C. (2002). Emotional intelligence and life satisfaction. Personality and Individual Differences, 33, 10911100.

Pehlivan, İ. (1995). Yönetimde stres kaynaklart. Ankara: Personel Geliştirme Merkezi.

Peterson, M. F., Smith, P. B, Akande, A. \& Ayestaran, S. (1995). Role conflict, ambiguity, and overload: A 21nation study. Academy of Management Journal, 38, 429-452.

Pritchard R. D. \& Karasick B. W. (1973). The effects of organizational climate on managerial job performance and job satisfaction. Organizational Behavior and Human Performance, 9, 126-146.

Recepoğlu, E. (2013). Öğretmen adaylarının yaşam doyumları ile ögretmenlik mesleğine ilişkin tutumları arasındaki ilişkinin incelenmesi. Hacettepe Üniversitesi Ĕ̌itim Fakültesi Dergisi, Özel Sayı (1), 311-326.

Reid, G. B. \& Nygren, T. E. (1988). The subjective workload assessment technique: A scaling procedure for measuring mental workload. Advances in Psychology, 52, 185-218.

Revicki, D. A., May, H. J. \& Whitley, T. W. (1991). Reliability and validity of the work-related strain inventory among health professionals. Behav. Med., $17,11-120$

Ross, A. (1994). Trust as a moderator of the effect of performance evaluation style on job related tension: a research note. Accounting, Organizations and Society, 19, 629-635.

Qureshi, M. I., Iftikhar, M., Abbas, S. G., Hassan, U., Khan K. \& Zaman. K. (2013). Relationship between job stress, workload, environment and employees turnover intentions: What we know, what should we know. World Applied Sciences Journal, 23(6), 764770.

Saari, M. L. \& Judge, A. T. (2004). Employee attitudes and jobsatisfaction. Human Resource Management, 43(4), 395-407.

Sabuncuoğlu, Z. \& Tüz, M. (2003). Örgütsel psikoloji. Bursa: Furkan Ofset.

Sapmaz, F. \& Doğan, T. (2012). Mutluluk ve yaşam doyumunun yordayıc1s1 olarak iyimserlik. Mersin Üniversitesi Ĕ̆itim Fakültesi Dergisi, 8(3), 63-69.
Schappe, S. P. (1998). The influence of job satisfaction, organizational commitment, and fairness perceptions on organizational citizenship behavior. The Journal of Psychology, 132(3), 277-90.

Schermelleh-Engel, K., Moosbrugger, H. \& Müller, H. (2003). Evaluating the fit of structural equation models: Tests of significance and descriptive goodness-of-fit measures. Methods of Psychological Research Online, 8(2), 23-74.

Selye, H. (1974). Stress without distress. Philadelphia: Lipincott.

Sparks, S., Corcoran, K., Nabors, L. \& Hovanitz, C. (2005). Subjective well-being and job satisfaction in nurses. Journal of Applied Social Psychology, 5(5), 922-938.

Sünter, T. A., Canbaz, S., Dabak, Ș. Öz, H. \& Pekșen, Y. (2006). Pratisyen hekimlerde tükenmişlik, işe bağlı gerginlik ve iş doyumu düzeyleri. Genel Tip Dergisi, 16(1), 9-14

Sy, T., Tram, S. \& O'Hara, L. A. (2006). Relation of employee and manager emotional intelligence to job satisfaction and performance. Journal of Vocational Behavior, 68, 461-473.

Şahin, F. (2011). Liderin kültürel zekâsının astların örgütsel vatandaşlık davranışı ile iş doyumu üzerine etkisi. Savunma Bilimleri Dergisi, 10(2), 80-104.

Şeker, B. D. \& Zırhlığlu, G. (2009). Van emniyet müdürlüğü kadrosunda çalışan polislerin tükenmişlik, iş doyumu ve yaşam doyumları arasındaki ilişkilerin değerlendirilmesi. Polis Bilimleri Dergisi, 11(4), 126.

Şimşek, E. \& Aktaş, H. (2014). Örgütsel sessizlik ile kişilik ve yaşam doyumu etkileşimi: Kamu sektöründe bir araștırma. Anadolu University Journal of Social Sciences, 14(2), 121-136.

Tait, M., Padgett, M. Y. \& Baldwin, T. T. (1989). Job and life satisfaction: A reevaluation of the strength of the relationship and gender effects as a function of the date of the study. Journal of Applied Psychology, 74(3), 502-507.

Tayfur, Ö. \& Arslan, M. (2012). Algılanan iş yükünün tükenmişlik üzerine etkisi: İş-aile çatışmasını aracıllk rolü. H. Ü. Íktisadi ve İdari Bilimler Fakültesi Dergisi, 30(1), 147-172.

Tel, H., Aydın, T. C. Karabey, G., Vergi, İ. \& Akay, D. (2012). Hemşirelerde işe bağlı gerginlik ve stresle başetme durumu. Cumhuriyet Hemşirelik Dergisi, 2, 47-52.

Telef, B. B. (2011). Öğretmenlerin öz-yeterlikleri, iş doyumları, yaşam doyumları ve tükenmiş̧liklerinin incelenmesi. Ilköğretim Online, 10(1), 91-108. 
Tett, R. P. \& Meyer, J. P. (1993). Job satisfaction, organizational commitment, turnover intention, and turnover: path analyses based on metaanalytic findings. Personnel Psychology, 46, 259-293.

Tokuç, B., Turunç, Y. \& Ekuklu, G. (2015). Edirne'de ambulans çalışanlarının anksiyete, depresyon ve işe bağlı gerginlik düzeyleri. Mesleki Sağllk ve Güvenlik Dergisi, 39-44.

Topkaya, N. \& Kavas, B. A. (2015). Algilanan sosyal destek, yaşam doyumu, psikolojik yardım almaya ilişkin tutum ve niyet arasındaki ilişkiler: Bir model çalışması. Turkish Studies, 10(2), 979-996.

Turgut, T. (2011). Çalışmaya tutkunluk: İş yükü, esnek çalışma saatleri, yönetici desteği ve iş- aile çatışması ile ilişkileri. Atatürk Üniversitesi İktisadi ve İdari Bilimler Dergisi, 25(3-4), 155-179.

Ünal, S., Karlıdağ, R. \& Yoloğlu, S. (2001). Hekimlerde tükenmişlik ve iş doyumu düzeylerinin yaşam doyumu düzeyleri ile ilişkisi. Klinik Psikiyatri Dergisi, 4, 113-118.

Van, D. H. M. \& Geurts, S. (2001). Associations between ovetime and psychological health in high and level reward jobs. Work Stres, 15, 3-17.

Veenhoven, R. (1991). Is happiness relative? Social Indicators Research, 24, 1-34.

Welsch, H. (2009). Implications of happiness research for environmental economics. Ecological Economics, 68, 2735-2742.

Yıldırım, F. (2007). İş doyumu ile örgütsel adalet ilişsisi. Ankara Üniversitesi SBF Dergisi, 62(1), 253-278.

Wilkins, K. \& Beaudet, M.P. (1998). Work stress and health. Health Reports, 10(3), 47-62.

Yiğit, R. (2012). Çevik kuvvet görevlilerinin benlik saygıları ile yaşam doyumu ve stresle başa çıkma tutumları arasındaki ilişkinin incelenmesi. Ahi Evran Üniversitesi Kırşehir Eğitim Fakültesi Dergisi, 13(1), 61-75.

Yüksel, İ. (2003). Hemşirelerin iş güçlügünü oluşturan değişkenlerin iş doyumu, iş gerilimi ve örgütsel bağl1lı üzerindeki etkisinin analizi. Firat Üniversitesi Sosyal Bilimler Dergisi, 13(1), 261- 272.

Yürür, Ş. \& Keser, A. (2010). İşe bağl1 gerginlik ile iş tatmini ilişkisinde duygusal tükenmenin aracı rolü. Ankara Üniversitesi SBF Dergisi, 65(4), 165-193. 